\title{
Intricacies of the Molecular Machinery of Catecholamine Biosynthesis and Secretion by Chromaffin Cells of the Normal Adrenal Medulla and in Pheochromocytoma and Paraganglioma
}

\author{
Annika M.A. Berends ${ }^{1, *}{ }^{\circ}$, Graeme Eisenhofer ${ }^{2}$, Lauren Fishbein ${ }^{3}$, \\ Anouk N.A. van der Horst-Schrivers ${ }^{1}$, Ido P. Kema ${ }^{4}$, Thera P. Links ${ }^{1}$, \\ Jacques W.M. Lenders ${ }^{5,6}$ and Michiel N. Kerstens ${ }^{1}$ \\ 1 Department of Endocrinology, University of Groningen, University Medical Center Groningen, \\ 9700 RB Groningen, The Netherlands \\ 2 Department of Clinical Chemistry and Laboratory Medicine and Department of Medicine III, \\ University Hospital Carl Gustav Carus, Technical University Dresden, 01069 Dresden, Germany \\ 3 Division of Endocrinology, Metabolism and Diabetes and Division of Biomedical Informatics and \\ Personalized Medicine, Department of Medicine, University of Colorado School of Medicine, \\ University of Colorado Cancer Center, Aurora, CO 80045, USA \\ 4 Department of Laboratory Medicine, University of Groningen, University Medical Center Groningen, \\ 9700 RB Groningen, The Netherlands \\ 5 Department of Medicine III, University Hospital Carl Gustav Carus, Technical University Dresden, \\ 01307 Dresden, Germany \\ 6 Department of Internal Medicine, Radboud University Medical Center, 6525 GA Nijmegen, The Netherlands \\ * Correspondence: m.a.berends@umcg.nl
}

Received: 22 June 2019; Accepted: 12 July 2019; Published: 6 August 2019 updates

\begin{abstract}
The adrenal medulla is composed predominantly of chromaffin cells producing and secreting the catecholamines dopamine, norepinephrine, and epinephrine. Catecholamine biosynthesis and secretion is a complex and tightly controlled physiologic process. The pathways involved have been extensively studied, and various elements of the underlying molecular machinery have been identified. In this review, we provide a detailed description of the route from stimulus to secretion of catecholamines by the normal adrenal chromaffin cell compared to chromaffin tumor cells in pheochromocytomas. Pheochromocytomas are adrenomedullary tumors that are characterized by uncontrolled synthesis and secretion of catecholamines. This uncontrolled secretion can be partly explained by perturbations of the molecular catecholamine secretory machinery in pheochromocytoma cells. Chromaffin cell tumors also include sympathetic paragangliomas originating in sympathetic ganglia. Pheochromocytomas and paragangliomas are usually locally confined tumors, but about $15 \%$ do metastasize to distant locations. Histopathological examination currently poorly predicts future biologic behavior, thus long term postoperative follow-up is required. Therefore, there is an unmet need for prognostic biomarkers. Clearer understanding of the cellular mechanisms involved in the secretory characteristics of pheochromocytomas and sympathetic paragangliomas may offer one approach for the discovery of novel prognostic biomarkers for improved therapeutic targeting and monitoring of treatment or disease progression.
\end{abstract}

Keywords: PPGL; catecholamines; adrenomedullary function 


\section{Introduction}

The adrenal medulla occupies the central portion of the adrenal gland and accounts for about $10 \%$ of total adrenal gland volume [1]. The adrenal medulla is essentially a specialized sympathetic ganglion releasing hormones in response to neural input and therefore is an integral part of the autonomic nervous system $[2,3]$. The adrenomedullary chromaffin cells are embryologically derived from migrating neural crest cells that develop into sympathoadrenal progenitors $[4,5]$. These sympathoadrenal progenitor cells also give rise to the chromaffin cells present in the sympathetic chain and prevertebral paraganglia. During adrenal organogenesis, close interactions between its two components, medulla and cortex, are necessary for differentiation, morphogenesis, and survival of the adrenal gland. This cortical-chromaffin crosstalk remains important for physiological regulation of adrenal hormone biosynthesis in adult life and also is relevant for the pathogenesis of various adrenal gland disorders [6-9]. One of the histological infrastructural requirements for this crosstalk is the centripetally directed arterial blood flow from adrenal cortex to medulla. In addition, cortical cells are diffusely present in the adrenal medulla and, conversely, chromaffin cells are intermixed with cortical cells within all three zones of the adrenal cortex [10].

The principal function of the adrenal medulla is the biosynthesis and the secretion into the circulation of the catecholamine epinephrine [6,11]. Epinephrine has a crucial role in the "fight-or-flight" response, which allows an organism to adapt to stressful conditions. The acute rise in epinephrine in response to physical or psychological stress stimuli results in hemodynamic and metabolic effects that modulate various functions such as blood pressure, cardiac output, and blood glucose by acting on cells expressing $\alpha$ - and $\beta$ - adrenergic receptors $[12,13]$. Under basal conditions, however, epinephrine functions as a circulating metabolic hormone, and it is the norepinephrine secreted by sympathetic nerves acting immediately in the vicinity of exocytotic secretion that is the catecholamine mainly regulating cardiovascular function. The norepinephrine that escapes re-uptake processes to enter the circulation has negligible impact on the cardiovascular system. Nevertheless, both norepinephrine and epinephrine secreted by pheochromocytomas in excessive amounts directly into the circulation can have profound effects on cardiovascular function, with further impacts of co-secreted peptides. From a clinical perspective, these tumors are the most important disease of the adrenal medulla. Chromaffin cell tumors may also arise in extra-adrenal sympathetic paraganglia, in which case they are termed sympathetic paragangliomas [14-16].

A cardinal feature of chromaffin cell tumors is their capacity to produce and secrete excessive amounts of catecholamines, which may evoke signs and symptoms such as paroxysmal hypertension, sweating, and tachycardia. The hypersecretion of catecholamines may cause acute, life-threatening blood pressure elevations and arrhythmias and is associated with a significantly increased rate of cardiovascular morbidity and mortality [17-20].

Pheochromocytomas and sympathetic paragangliomas are rare neuroendocrine tumors with respective reported annual incidences of 0.46 and 0.11 per 100,000 individuals [21]. Detected incidence of pheochromocytomas has doubled during the past two decades, most likely a result of changes in diagnostic practices leading to earlier detection. The cornerstone of biochemical diagnosis of a pheochromocytoma or a sympathetic paraganglioma is the demonstration of elevated plasma or urinary concentrations of metanephrine, normetanephrine, or 3-methoxytyramine, i.e., the O-methylated metabolites of epinephrine, norepinephrine, or dopamine, respectively [22]. Several anatomical and functional imaging studies are available for localization of the tumor, after which curative treatment by surgical resection can be offered [23].

Pheochromocytomas and paragangliomas are highly heterogeneous neuro-endocrine tumors with regards to possible anatomic location, genetic context, symptomatology, metastatic potential, and the degree of catecholamine release. Genetic mutations play a critical role in tumorigenesis and affect various metabolic pathways, which also result in different mutation-dependent biochemical phenotypes [3,24-26]. 
In recent years, our knowledge of the genotype-phenotype interrelationship and metabolomics of these intriguing neuro-endocrine tumors has expanded rapidly. Nevertheless, there are still several areas of uncertainty. For instance, in the absence of metastases, it is difficult to predict whether a pheochromocytoma or a paraganglioma will demonstrate a benign or a malignant clinical course [16]. There are no clear-cut pathological markers to establish malignancy with certainty at first presentation. Also, there is no straightforward relationship between the biochemical phenotype of a pheochromocytoma or sympathetic paraganglioma and the associated signs or symptoms [3]. In the present review, we aim to provide a detailed picture of the pathways involved in catecholamine production and secretion in normal adrenomedullary chromaffin cells. We also visit what is known about the molecular perturbations in catecholamine biosynthesis and secretion in pheochromocytoma and sympathetic paraganglioma. Improved understanding of these mechanisms at the molecular level might provide insight into associated pathological complications, clarify highly variable presentations, and aid in identification of new diagnostic or therapeutic strategies for personalized care.

\section{Adrenomedullary Function}

\subsection{Biosynthesis of Catecholamines}

Adrenomedullary catecholamine biosynthesis starts with uptake of the nonessential amino acid L-tyrosine by the chromaffin cell. L-tyrosine is obtained from food sources or is derived from the essential amino acid phenylalanine through the activity of phenylalanine hydroxylase, which is mainly expressed in liver, kidney, and pancreas [27,28]. L-tyrosine is transported into the cytoplasm of the adrenal chromaffin cell by the membrane bound L-type amino acid transporter system (LAT1 and LAT2) $[29,30]$. Catecholamine biosynthesis involves the sequential activity of four enzymes: tyrosine hydroxylase (TH), aromatic L-amino acid decarboxylase (AADC), dopamine $\beta$-hydroxylase (DBH), and phenylethanolamine- $N$-methyltransferase (PNMT). Except for DBH, all these enzymes are localized in the cytoplasm of the chromaffin cell (Figure 1). The end products of this biosynthetic route are dopamine, norepinephrine, or epinephrine, depending on intracellular enzyme expression. Epinephrine is mainly produced by the adrenomedullary chromaffin cells $(>95 \%)$ and functions as a hormone released directly into the bloodstream. In contrast, circulating norepinephrine is mainly derived from overflow of the neurotransmitter from sympathetic nerve endings with adrenomedullary chromaffin cell production providing usually a less than $10 \%$ contribution $[11,13,31]$.

\subsubsection{Tyrosine Hydroxylase}

The initial and rate limiting step in catecholamine biosynthesis is the conversion of L-tyrosine to L-3,4-dihydroxyphenylalanine (L-DOPA) by tyrosine hydroxylase (TH, EC 1.14.16.2, molecular mass of approximately $240 \mathrm{kDa}$ ) [32,33]. Locations of catecholamine biosynthesis are therefore dependent on the expression of $\mathrm{TH}$, which is largely confined to postganglionic sympathetic nerve endings and adrenal and extra-adrenal chromaffin cells. In the adrenal medulla, this enzyme has a $\mathrm{Km}$ of $2 \times 10^{-5} \mathrm{~mol} / \mathrm{L}$ [27]. For this specific hydroxylation step, TH requires tetrahydrobiopterin, molecular oxygen, and $\mathrm{Fe}^{2+}$ as cofactors. Tetrahydrobiopterin is synthesized from guanosine triphosphate (GTP) and serves as a donor for hydrogen atoms to maintain TH in a reduced and active state [27,34]. The human TH gene is located at chromosome 11p15.5 and contains 13 exons [35], with four isoforms produced by alternative mRNA splicing.

Regulation of TH activity is an important way to control catecholamine biosynthesis. This is a complex process encompassing multiple modes of regulation. Short-term post-transcriptional mechanisms include feedback inhibition by catecholamines, enzyme phosphorylation and dephosphorylation, as well as ubiquitination. Long-term regulation mainly involves transcriptional mechanisms [36]. The ubiquitin-proteasome pathway is thought to be involved in the degradation of TH [37]. Catecholamines exert negative feedback control through oxidation of tetrahydrobiopterin to pteridine, thereby preventing the formation of $\mathrm{TH}$ in its reduced active state [27]. In addition, 
catecholamines act as competitive antagonists of tetrahydrobiopterin at the active site of the catalytic domain of TH [27]. Short-term regulation of TH activity is also achieved by a mechanism of phosphorylation and dephosphorylation of one or more of the four serine residues at the regulatory site of TH. Phosphorylation is catalyzed by multiple kinases (e.g., PKA, PKC, CaMKII, MAPKAP-K2, ERK1, ERK2, MSK1, PRAK) and results in release from the feedback inhibition by catecholamines, thereby stimulating enzyme activity.

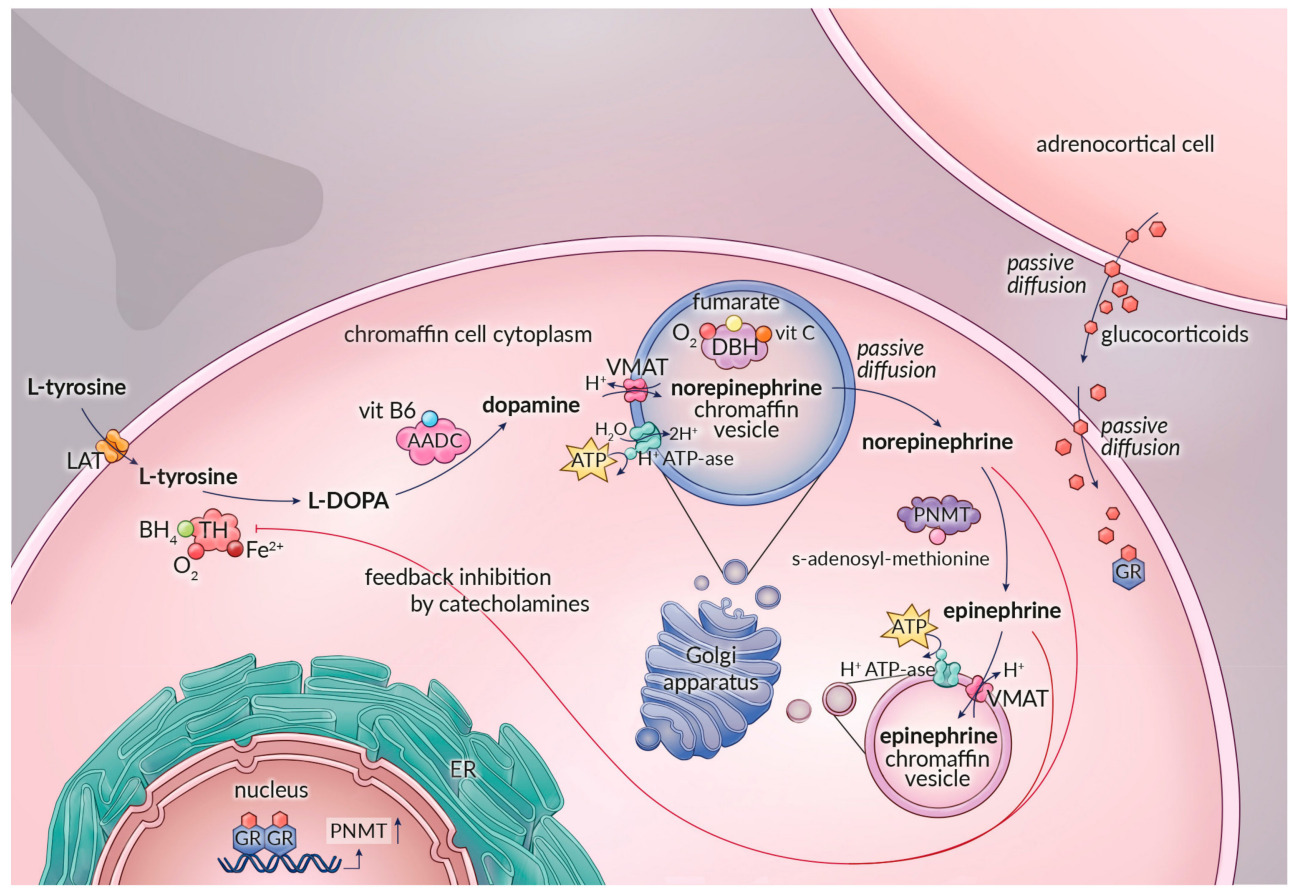

Figure 1. The catecholamine biosynthetic pathway in an adrenomedullary chromaffin cell or a pheochromocytoma cell. Norepinephrine and epinephrine are stored in separate chromaffin storage vesicles. Abbreviations: LAT: L-type amino acid transporter; TH: tyrosine hydroxylase; L-DOPA: L-3,4-dihydroxyphenylalanine; AADC: aromatic L-amino acid decarboxylase; DBH: dopamine $\beta$-hydroxylase; PNMT: phenylethanolamine-N-methyltransferase; BH4: tetrahydrobiopterin; 02: molecular oxygen; VitB6: pyridoxalphosphate; VitC: ascorbate; VMAT: vesicular monoamine transporters; GR: glucocorticoid receptor.

Dephosphorylation by phosphatase PP2A, and to a lesser extent by PP2C, restores catecholaminergic inhibition of the TH enzyme [36]. This negative feedback is mediated via alpha2-adrenergic or D2-dopaminergic receptors, which activate cyclic adenosine monophosphate (cAMP) or $\mathrm{Ca}^{2+} /$ calmodulin-dependent protein phosphatases [27]. Prolonged stimulation of catecholamine biosynthesis results in induction of TH protein synthesis through several cAMP dependent pathways activating $T H$ gene transcription $[27,34,36,38-40]$.

Given the importance of its activity to catecholamine synthesis and the complexity of its regulation, TH has gained great interest in many fields of biomedical research. Recent studies, for example, have demonstrated the presence of several TH polymorphisms in the general population, some of which appear associated with increased norepinephrine levels and elevated blood pressure [35,41].

\subsubsection{Aromatic L-Amino Acid Decarboxylase}

The next step in catecholamine biosynthesis is the decarboxylation of L-DOPA to dopamine by cytosolic aromatic L-amino acid decarboxylase (AADC; EC 4.1.1.28). For this conversion, pyridoxalphosphate (vitamin B6) is required as a cofactor [27,42]. AADC is a $100 \mathrm{kDa}$ homodimeric protein encoded by a single gene located at chromosome 7p12.1 with a Km of $4 \times 10^{-4} \mathrm{~mol} / \mathrm{L}[42,43]$. The calculated $\mathrm{Km}$ greatly exceeds the endogenous concentration of L-DOPA, which means that 
the AADC enzyme is not fully saturated, and the rate at which dopamine can be synthesized is therefore limited by the availability of L-DOPA as a substrate [42]. The AADC enzyme has a wide tissue distribution and is not specific for chromaffin cells [42,44].

Short-term regulation of AADC enzyme activity by a previously postulated mechanism involving cAMP or phosphorylation by protein kinases seems to play no significant role in the regulation of the catecholamine biosynthetic pathway in situ [42,45]. The added value of AADC enzyme upregulation by modulation of gene expression for physiological demands to increase catecholamine production in postganglionic sympathetic nerve endings remains questionable [45-47].

\subsubsection{Dopamine $\beta$-hydroxylase}

In adrenal chromaffin cells, dopamine is further catalyzed to norepinephrine by dopamine $\beta$-hydroxylase (DBH; EC 1.14.17.1). Because of the intravesicular location of DBH, dopamine first must be translocated into norepinephrine storage vesicles by vesicular monoamine transporters (VMATs) [11] . The intravesicular conversion of dopamine represents the final step in the biosynthesis of norepinephrine. $\mathrm{DBH}$, a mixed-function oxidase, is a $290 \mathrm{kDa}$ copper protein with a $\mathrm{Km}$ of $8.4 \times 10^{-4} \mathrm{~mol} / \mathrm{L}$ and utilizes molecular oxygen, fumarate, and L-ascorbic acid as its main cofactors $[27,48,49]$. These requirements for L-ascorbic acid and fumarate are not specific. Catechol (i.e., pyrocatechol or 1,2 dihydroxybenzene) seems to be a weak substitute for L-ascorbic acid and other activating anions, such as acetate and chloride, which can replicate the effects of fumarate at least partially [27,48,50-52].

In humans, DBH is encoded by a gene located at chromosome 9q34.2. Increased catecholamine biosynthesis in response to stress is associated with increased levels of mRNAs encoding catecholamine synthesizing enzymes. In adrenomedullary chromaffin cells, this response to stress is rapid, especially for TH and PNMT [39]. Previous studies also revealed upregulation of adrenal DBH gene expression by various transcriptional mechanisms in response to prolonged or repeated stressors [39,53]. However, in contrast to $T H$, short or intermediate duration of stress does not result in a significant increase of DBH mRNA [39].

\subsubsection{Phenylethanolamine- $N$-Methyltransferase}

Norepinephrine formed in the chromaffin vesicles diffuses passively into the cytosol, where it is converted to epinephrine by the enzyme phenylethanolamine- $N$-methyl transferase (PNMT; EC 2.1.1.28) [11,24]. PNMT, which has a predicted molecular weight of $30.9 \mathrm{kDa}$ and a Km of $9.2 \times 10^{-6} \mathrm{~mol} / \mathrm{L}$, requires $S$-adenosylmethionine as a methyl donor and cosubstrate $[27,54,55]$. PNMT is not substrate specific and also is involved in the biosynthesis of other $N$-methylated trace amines [11,27]. Expression of PNMT is controlled by glucocorticoid receptor-mediated mechanisms, acting in concert with several other transcription factors such as Egr-1, AP2, Sp1, and MAZ [6,39,56,57]. The proximity of adrenocortical cells to the adrenal medulla guarantees high circulating glucocorticoid levels, which cross the chromaffin cell membrane through passive diffusion. Glucocorticoid binds to the intracytoplasmatic glucocorticoid receptor, and the receptor-hormone complex migrates to the cell nucleus and binds to the glucocorticoid response element of the promoter region of the PNMT gene located on chromosome 17q12, activating gene transcription $[7,58,59]$. This explains why the adrenal gland is the body's most important source of epinephrine, whereas the expression of extra-adrenal PNMT is limited to a small number of neurons in the central nervous system and to a subset of cardiomyocytes $[6,60,61]$.

\subsubsection{Co-Secreted Products}

Chromaffin cells of the adrenal medulla synthesize a large variety of other substances, such as neurotransmitters, enzymes, peptides, and proteins, which are also stored in chromaffin vesicles and co-secreted along with catecholamines [62-64]. Over the past decades, the components of this vesicular cocktail have been studied in great detail (Table 1). 
Table 1. Overview of the co-secreted products of chromaffin vesicles with description of their function in normal adrenal medulla and reported alterations in pheochromocytoma and paraganglioma (PPGL).

\begin{tabular}{|c|c|c|}
\hline Component & Function in Human Adrenal Medulla & Reported Alterations in PPGL \\
\hline \multicolumn{3}{|l|}{ Granins } \\
\hline Chromogranin A-C [65-77] & $\begin{array}{l}\text { Role in vesiculogenesis, vesicle protein stability, hormone storage within vesicles. } \\
\text { Sorting proteins in the regulated secretory pathway. } \\
\text { Precursor protein for several peptides; chromogranin A (vasostatin I-II, catestatin, } \\
\text { cateslytin, chromacin, chromofungin, pancreastatin, parastatin, WE-14, EL35), } \\
\text { chromogranin B (secretolytin), chromogranin C (secretoneurin, EM66, manserin). }\end{array}$ & $\begin{array}{c}\begin{array}{c}\text { Higher plasma levels of chromogranin A and B are reported in PPGL compared to } \\
\text { healthy volunteers. }\end{array} \\
\text { Chromogranin C mRNA was overexpressed in PPGL compared to non-tumoral } \\
\text { chromaffin tissue. }\end{array}$ \\
\hline Secretogranins III-VII [78-87] & $\begin{array}{l}\text { Secretogranin III (syn. 1B1075) not found in adrenal medulla. } \\
\text { Presence of secretogranin IV (syn. HISL-19), V (syn. 7B2), VI (syn. NESP55) and VII } \\
\text { (VGF) reported in human adrenal medulla, exact function still mainly unknown. } \\
\text { Proposed role of secretogranin VII (syn. VGF) in the regulation of } \\
\text { energy homeostasis. }\end{array}$ & $\begin{array}{l}\text { More pronounced immunoreactivity of secretogranin IV in malignant PPGL } \\
\text { compared to benign PPGL. } \\
\text { Significantly higher plasma levels of secretogranin V in PPGL compared to } \\
\text { age-matched normal subjects. } \\
\text { Secretogranin VI immunoreactivity found in PPGL with no differences between } \\
\text { benign and malignant tumors. Variable proVGF-immunoreactive fragments are } \\
\text { observed in human PPGL. }\end{array}$ \\
\hline
\end{tabular}

\section{Glycoproteins}

Glycoprotein I, i.e., DBH, catalyzes the conversion of dopamine into

Glycoprotein I-V [88-90]

High expression levels of glycoprotein I (DBH) are reported in PPGL.

\begin{tabular}{cc}
\hline Prohormone processing enzymes & driving force for vesicular uptake of catecholamines by \\
\hline Aminopeptidase B (Ap-B) [91] & Exopeptidase involved in final conversion of proenkephalin to enkephalin. \\
\hline Aspartic Proteinase [92] & Contributes to enkephalin precursor cleaving activity. \\
\hline Carboxypeptidase E (CPE) [93,94] & Role in peptide processing and sorting of prohormones.
\end{tabular}

Carboxypeptidase E (CPE) [93,94]

Role in peptide processing and sorting of prohormones.

Association of Ap-B with the secretory machinery is suggested in rat pheochromocytoma (PC12) cells.

Endopeptidase involved in proteolysis of proenkephalin into (Met)enkephalin.
Proprotein convertase for biosynthesis of NPY and catestatin.

Prohormone convertase $1 / 3$ and $2[73,78,97]$

Tissue-Type Plasminogen Activator (t-PA) $[98,99]$
Conversion of chromogranin C into secretoneurin and EM66.

Participation in plasmin-dependent processing of bioactive peptides including chromogranin A and indirectly modulate chromogranin A release (negative-feedback loop).

\section{Unknown}

High expression of CPE mRNA are reported. Elevated expression correlated with tumor growth and metastasis in pheochromocytomas.

CPE promotes survival of pheochromocytoma (PC12) cells under nutrient starvation and hypoxic conditions by upregulation of pro-survival genes possibly

$$
\text { by activation of the ERK1/2 pathway. }
$$

$P C 1$ and $P C 2$ mRNA expression levels are significantly higher in benign and malignant PPGL compared to normal adrenal medulla. mRNA expression and protein levels of $P C 1$ and $P C 2$ is 3-4 times higher in benign tumors compared to malignant tumors.

Marked expressions of t-PA mRNA are reported in human pheochromocytomas. 
Table 1. Cont.

\begin{tabular}{|c|c|c|}
\hline Component & Function in Human Adrenal Medulla & Reported Alterations in PPGL \\
\hline \multicolumn{3}{|l|}{ Granins } \\
\hline \multicolumn{3}{|l|}{ Inhibitors of endogenous proteases } \\
\hline Endopin 1-2 [100] & $\begin{array}{l}\text { Endopin } 1 \text { inhibits trypsin-like serine proteases. } \\
\text { Endopin } 2 \text { inhibits papain-like cysteine proteases, including cathepsin L, as well as } \\
\text { the serine protease elastase. }\end{array}$ & Unknown \\
\hline \multicolumn{3}{|l|}{ Transmitter peptides } \\
\hline Adrenomedullin $[65,101-105]$ & $\begin{array}{l}\text { Increases blood flow in the adrenal gland. Increases catecholamine release. Induces } \\
\text { systemic vasodilation. Increases natriuresis. }\end{array}$ & $\begin{array}{l}\text { High plasma levels are reported, especially in PPGL patients with high } \\
\text { blood pressure. }\end{array}$ \\
\hline Bombesin [106-108] & $\begin{array}{l}\text { Modulation of stress response. Paracrine regulatory effects on growth, structure } \\
\text { and function of the adrenal cortex. }\end{array}$ & $\begin{array}{l}\text { Highly variable immunoreactivity in pheochromocytomas and paragangliomas. } \\
\text { An association between clinically malignant PPGL and lower expression of bombesin } \\
\text { is postulated. }\end{array}$ \\
\hline $\begin{array}{l}\text { Calcitonin Gene-Related } \\
\quad \text { Peptide }[109,110]\end{array}$ & $\begin{array}{l}\text { Vasodilatation, enhances aldosterone and corticosterone release by } \\
\text { adrenocortical cells. }\end{array}$ & Slightly elevated levels are reported. \\
\hline Catestatin, Cateslytin [111,112] & $\begin{array}{l}\text { Inhibits release of catecholamines, chromogranin A, NPY, and ATP by acting as } \\
\text { noncompetitive antagonist of the nicotinic receptor. }\end{array}$ & Unknown \\
\hline EM66 (via PACAP) [73,113,114] & $\begin{array}{l}\text { Derivate from chromogranin C (syn. secretogranin II). Synthesis and secretion } \\
\text { regulated by PACAP. Paracrine regulation of steroidogenic cells in the adrenal gland. }\end{array}$ & Elevated in PPGL. Higher levels of EM66 reported in benign vs. malignant PPGL. \\
\hline $\begin{array}{l}\text { Natriuretic peptides (ANP, BNP, } \\
\text { CNP) }[102,115,116]\end{array}$ & $\begin{array}{l}\text { Autocrine/paracrine inhibition of catecholamine secretion via the ANF-R2 receptor } \\
\text { subtype. Inhibition of aldosterone production by a direct action on the adrenal } \\
\text { cortex both in vivo and in vitro. }\end{array}$ & Elevated in PPGL patients with high blood pressure. \\
\hline $\begin{array}{l}\text { Neuropeptide Y (NPY) } \\
{[65,76,101,117-122]}\end{array}$ & $\begin{array}{l}\text { Increases catecholamine biosynthesis (stimulates } T H \text { gene expression) and secretion. } \\
\text { Potentiates catecholamine induced vasoconstriction. }\end{array}$ & $\begin{array}{l}\text { Influence on tumorigenesis and stimulation of neoangiogenesis is described. High } \\
\text { levels of NPY mRNA have been found in benign tumors, whereas its plasma levels } \\
\text { are elevated in patients with malignant PPGL. } \\
\text { Significantly lower expression level of NPY in VHL associated PPGL compared to } \\
\text { other hereditary and sporadic PPGL is reported. }\end{array}$ \\
\hline Neurotensin $[123,124]$ & $\begin{array}{l}\text { Not detected in human adrenal medulla. Various central and peripheral effects have } \\
\text { been postulated in bovine, cat and rat, e.g., hypotension, hypothermia, analgesia. }\end{array}$ & Neurotensin has rarely been demonstrated in human PPGL. \\
\hline $\begin{array}{l}\text { Opioid peptides (enkephalins, } \\
\text { endorphins) }[96,117,125-128]\end{array}$ & $\begin{array}{l}\text { Decrease catecholamine release via binding } \mathrm{G}_{i} \text { protein coupled receptor resulting in } \\
\text { inhibition of } \mathrm{Ca}^{2+} \text { channels } \\
\text { Analgesia, enhancement of immune reaction. }\end{array}$ & $\begin{array}{l}\text { Enkephalin decreases norepinephrine release in human pheochromocytomas. } \\
\text { Different enkephalins (i.e., (Met)enkephalin, (Leu)enkephalin) are observed in } \\
\text { human pheochromocytomas. Expression of (Met) enkephalin and (Leu)enkephalin } \\
\text { is highly variable compared to normal adrenal medulla. Possible association } \\
\text { between malignant PPGL and lower expression of enkephalins. }\end{array}$ \\
\hline PACAP $[40,63,101,117,129,130]$ & $\begin{array}{l}\text { Induces transcription and stimulates activity of TH, DBH, and PNMT Stimulates } \\
\text { expression and secretion of several other peptides e.g., brain natriuretic peptide, } \\
\text { enkephalins, EM66, and secretoneurin. }\end{array}$ & $\begin{array}{l}\text { High mRNA expression of PACAP and PAC1-R in PPGL reported. Comparable } \\
\text { expression levels in benign and metastatic PPGL found in a relatively small series. }\end{array}$ \\
\hline Secretoneurin (via PACAP) [131-133] & $\begin{array}{l}\text { Derivate from chromogranin C (syn. secretogranin II). Synthesis and secretion } \\
\text { regulated by PACAP. Role in angiogenesis and modulation of inflammatory } \\
\text { response by chemoattractant effects on monocytes, eosinophils, fibroblasts, vascular } \\
\text { smooth muscle cells, and endothelial cells. }\end{array}$ & Unknown \\
\hline
\end{tabular}


Table 1. Cont.

\begin{tabular}{|c|c|c|}
\hline Component & Function in Human Adrenal Medulla & Reported Alterations in PPGL \\
\hline $\begin{array}{l}\text { Transforming Growth Factor } \\
\beta[134-136]\end{array}$ & $\begin{array}{l}\text { Role in regulation of chromaffin cell proliferation and differentiation. Reduction of } \\
\text { TGF } \beta \text { has been shown to increase proliferation of chromaffin cell in vivo. }\end{array}$ & Unknown \\
\hline \multicolumn{3}{|l|}{ Granins } \\
\hline Vasostatins [137-139] & $\begin{array}{l}\text { The N-terminal fragment of chromogranin A } \\
\text { Inhibition of endothelin-induced vasoconstriction } \\
\text { Antibacterial and antifungal activity. }\end{array}$ & Unknown \\
\hline \multicolumn{3}{|l|}{ Anti-bacterial/anti-fungal peptides } \\
\hline Chromacin P, G and PG [140] & Antibacterial activity against Gram positive bacteria. & Unknown \\
\hline Secretolytin [141] & Antibacterial activity against Gram positive bacteria. & Unknown \\
\hline Ubifungin [142] & Antifungal activity. & Unknown \\
\hline \multicolumn{3}{|l|}{ Other minor components } \\
\hline Ascorbic acid [143] & Regulation of DBH activity. & Unknown \\
\hline $\begin{array}{c}\text { Coenzyme A glutathione } \\
\text { disulfide [144] }\end{array}$ & Vasoconstriction, modulation of AngII effects. & Unknown \\
\hline Ions $\left(\mathrm{Ca}^{2+}, \mathrm{Na}^{+}, \mathrm{K}^{+}, \mathrm{Mg}^{2+}, \mathrm{Cl}^{-}\right)[145]$ & Regulation of exocytosis. & Unknown \\
\hline Galanin $[81,146,147]$ & Stimulation of norepinephrine and glucocorticoid secretion. & $\begin{array}{c}\text { Immunoreactivity in human PPGL. } \\
\text { Higher levels reported in PPGL compared to normal adrenal medulla. } \\
\text { Variable expression; galanin was predominantly found in noradrenergic } \\
\text { pheochromocytoma cells. } \\
\text { Induction of apoptosis in PC12 cells. } \\
\text { Inhibition of dopamine secretion in pheochromocytoma cells. }\end{array}$ \\
\hline Nucleotides (ATP, ADP, GTP) [148] & $\begin{array}{l}\text { Formation of intravesicular complex with catecholamines, buffer function, } \\
\text { decreases intravesicular osmotic pressure, neuromodulation. }\end{array}$ & Unknown \\
\hline Substance P [149-153] & $\begin{array}{l}\text { Inhibition of nicotinic acetylcholine receptor mediated } \\
\text { catecholamine release. Vasodilation. }\end{array}$ & $\begin{array}{l}\text { Variable immunoreactivity demonstrated in human pheochromocytomas. Elevated } \\
\text { plasma levels in minority of patients. }\end{array}$ \\
\hline $\begin{array}{l}\text { Vasoactive intestinal } \\
\text { polypeptide [154-156] }\end{array}$ & Stimulation of catecholamine release, stimulation of steroid secretion. & Few cases described of human PPGL with concomitant excessive VIP secretion. \\
\hline
\end{tabular}

Abbreviations: ANF-R2, atrial natriuretic factor receptor subtype 2; AngII, angiotensin II; CGA, Chromogranin A; CGB, Chromogranin B; CGC, Chromogranin C; DBH, dopamine $\beta$-hydroxylase; HISL-19, human islet cell antigen 19; NESP55, neuroendocrine secretory protein 55; NPY, Neuropeptide Y; PACAP, pituitary adenylate cyclase-activating polypeptide;

PAC1-R, PACAP-preferring receptor; PC, Prohormone-Converting Enzymes; TH, tyrosine hydroxylase. 
Among these substances, chromogranin A and the trophic and secretion stimulating peptides pituitary adenylate cyclase-activating polypeptide (PACAP), neuropeptide Y (NPY), and adrenomedullin (AM) have gained the most attention because of their endocrine, paracrine, and autocrine effects, their importance for vesiculogenesis, and their possible roles in neoplastic chromaffin cell proliferation, differentiation, and survival, as further discussed below [62-65,101,113,129,157].

\subsection{Storage and Secretion of Catecholamines}

\subsubsection{Storage and Vesicular Transmembrane Dynamics}

In adrenomedullary chromaffin cells, catecholamines are stored in specialized vesicles. The bidirectional vesicular-cytosolic exchange of catecholamines is a dynamic process of active uptake into these chromaffin storage vesicles and passive leakage from vesicles into the cytosol [3]. After synthesis, dopamine and epinephrine are actively transported from the cytosol into chromaffin storage vesicles by vesicular monoamine transporters (VMAT1 and VMAT2) [158,159]. The driving force for this active transport is provided by an ATP-dependent vesicular membrane proton pump that maintains a transvesicular hydrogen ion $\left(\mathrm{H}^{+}\right)$electrochemical gradient by acidifying the vesicle matrix. Vesicular uptake for catecholamines via VMAT is accompanied by exchange of an $\mathrm{H}+$ ion from the vesical matrix towards the cytosol [62,160] (Figure 1).

\subsubsection{Characteristics of Chromaffin Storage Vesicles}

Chromaffin storage vesicles are highly specialized organelles of the chromaffin cells for storage and exocytosis. These membrane-bound electron-dense organelles originate from the Golgi network and are 150 to $350 \mathrm{~nm}$ in diameter. Each adrenomedullary chromaffin cell contains about 12,000 to 30,000 of these vesicles, corresponding (on average) to $13.5 \%$ of the cytoplasmic cell volume $[63,65]$.

The adrenal medulla of some species harbors two distinct populations of chromaffin cells, which either produce epinephrine or norepinephrine depending on the presence or the absence of PNMT $[3,11,63]$. The proportion of epinephrine versus norepinephrine producing chromaffin cells in the adrenal medulla varies between species, but the adrenergic phenotype usually predominates $[3,6,62,63,161]$. This is particularly so in humans, where most chromaffin cells appear to have mixed function $[6,11,62,161,162]$. Nevertheless, there are clear ultrastructural differences between epinephrine and norepinephrine-containing vesicles when studied by electron microscopy. Epinephrine-containing vesicles are round or elongated in shape and demonstrate fine granular, medium-density vesicles with a characteristic narrow and uniform peripheral halo, whereas norepinephrine-containing vesicles demonstrate a high density and homogeneous content with a limiting membrane, which may be separated from the matrix constituents by a prominent lucent halo.

The mechanisms initiating and regulating the biogenesis of chromaffin vesicles are largely unknown. It is believed that structural proteins of the granin family, in particular chromogranin A, have an important role in vesiculogenesis, providing structural domains that drive chromaffin vesicle formation in the Golgi network. Furthermore, the ability of chromogranin A to bind catecholamines is thought to regulate stability of the vesicle by reducing osmotic pressure, thereby preventing vesicles from bursting; it is also thought to protect catecholamines against enzymatic degradation until secretion is warranted $[27,63,65]$.

After the formation of chromaffin vesicles, maturation continues with catecholamine synthesis and storage not occurring until late in vesicle formation [63]. Fully matured chromaffin vesicles remain in the chromaffin cell until stimulation for exocytosis $[63,65]$.

The molecular composition of chromaffin vesicles is complex. Besides catecholamines, intravesicular contents include a diverse mixture of peptides, proteases, enzymes, and granins (chromogranins, secretogranins) with a multiplicity of functions (Table 1). The high concentration of regulatory and modulating peptides and proteins reflects broad endocrine, paracrine, and autocrine functions of adrenomedullary chromaffin vesicles. The physiological processes modulated by these 
constituents not only involve the fine-tuning of catecholamine biosynthesis and secretion but also encompass various analgesic, immunomodulatory, antimicrobial, and anti-inflammatory responses to cell stress $[62,63]$.

\subsubsection{Secretion and Re-Uptake of Catecholamines}

After exocytosis of storage vesicles and secretion of catecholamines into the bloodstream, norepinephrine and epinephrine are removed from the circulation by neural and extra-neuronal monoamine transporters and are inactivated by metabolizing enzymes [163]. The re-uptake mechanism through the norepinephrine transporter (NET) by catecholamine synthesizing cells is only relevant in sympathetic postganglionic and central nervous system neurons and provides rapid termination of the neurotransmitter signal at the postsynaptic membrane and enables recycling of catecholamines for re-release. NET is not only located presynaptically but also at several extraneuronal sites, including the adrenal medulla $[31,163,164]$. The precise function of the NET in the adrenal gland is, however, not entirely clear. A detailed discussion of reuptake as well as pre- and postsynaptic effects of catecholamines is beyond the scope of the current review, and for further reading, we refer to the literature $[163,165,166]$.

\subsection{Regulation of Adrenomedullary Activity}

\subsubsection{Stimulus-Dependent Exocytosis in Adrenal Chromaffin Cells}

Exocytosis of chromaffin storage vesicles is a tightly controlled process. Under basal conditions, only a few secretory vesicles are released into the circulation, resulting in a catecholamine secretion rate in the order of nanograms per minute [117]. Toxic effects of excessive chronic catecholamine release such as in heart failure, pulmonary edema, and malignant hypertension have been reported from incessant circulating catecholamine concentrations of $10^{-6} \mathrm{~mol} / \mathrm{L}$ or more, corresponding to the release of $5 \%$ of all adrenomedullary chromaffin vesicles [167]. In acute stress situations, the amount of released vesicles from the total adrenal gland can be temporarily greatly increased, with plasma catecholamine concentrations reaching up to 60 times more than normal $[117,167]$. Well-known stimuli that activate the exocytotic process are hypoglycaemia, hypovolemia, hypotension, hypoxemia, and severe pain or emotional distress [3].

The rather complex mechanisms regulating chromaffin cell exocytotic machinery are executed at neuronal and non-neuronal levels [145,167-169]. It is thought that each adrenomedullary chromaffin cell receives its own individual neuronal and non-neuronal input [167].

At a neuronal level, adrenomedullary chromaffin cells are innervated by the cholinergic preganglionic sympathetic fibers of the splanchnic nerve. One single chromaffin cell can receive input by up to five synapses [170]. Acetylcholine released by these nerve endings predominantly binds to nicotinic receptors on the chromaffin cell, resulting in membrane depolarization with subsequent calcium influx followed by stimulation of exocytosis and catecholamine secretion. Cholinergic receptors of the muscarinic type are also expressed on the chromaffin cell, but their contribution to catecholamine secretion is less important. Further enhancement of the stimulation-secretion coupling is provided by propagation of the secretion signal via gap junctions between chromaffin cells formed by connexins, which are specific proteins involved in cell-to-cell communication. This intercellular communication can be upregulated in stressful conditions [170]. Besides acetylcholine, splanchnic nerve terminals also contain PACAP as a neurotransmitter. This neuropeptide is not only stored in chromaffin vesicles and co-secreted with catecholamines but also acts as an important neurotransmitter at the splanchnic medullary synapse, where it activates the PACAP-preferring receptor (PAC1-R) on the postsynaptic membrane of the chromaffin cell. Laboratory experiments have shown that PACAP is only released at high frequencies of nerve stimulation, which is the firing rate occurring in stress conditions. In contrast to the acetylcholine evoked catecholamine secretion, adrenomedullary stimulation by PACAP is 
not susceptible to desensitization, which ensures robust catecholamine release under conditions of continuous stress (Figure 2) [40,130].

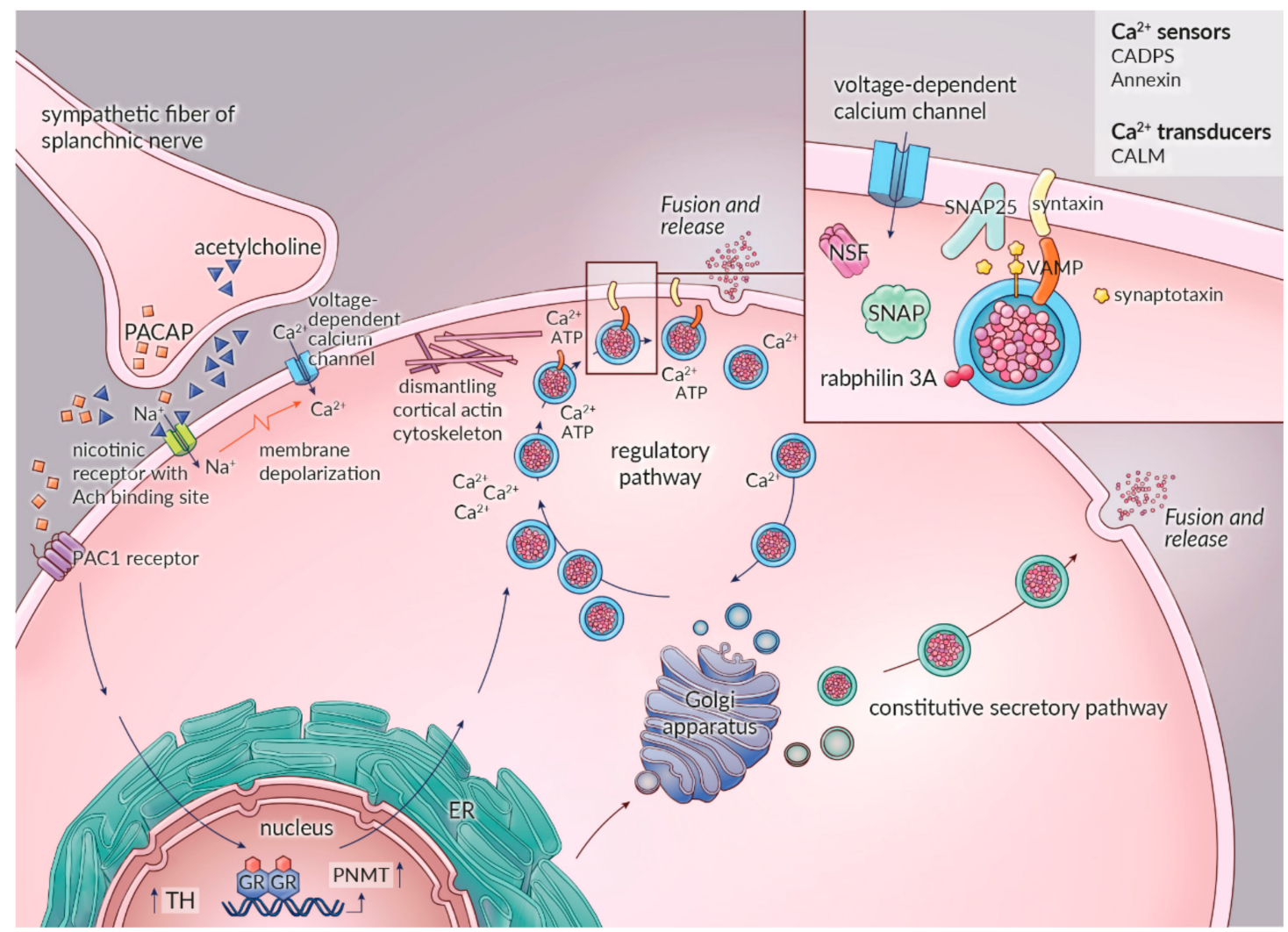

Figure 2. Schematic overview of the stimulation-secretion coupling in the adrenomedullary chromaffin cell with the multiple functionally definable stages and the different secretory pathways. Abbreviations: ER: endoplasmic reticulum; Ach: acetylcholine; VAMP: vesicle-associated membrane protein; SNAP: synaptosomal-associated protein; NSF: N-ethylmaleimide Soluble Factor proteins; CADPS: $\mathrm{Ca}^{2+}$ dependent secretion activator; CALM: calmodulin; PACAP: pituitary adenylate cyclase-activating polypeptide; PAC1 receptor: PACAP-preferring receptor; GR: glucocorticoid receptor.

Non-neuronal regulation of exocytosis occurs predominantly through autocrine or paracrine routes. As a result, cellular catecholamine secretion is partially under the influence of the exocytotic activity of neighboring chromaffin cells [167]. Furthermore, both lipopolysaccharide and cytokine receptors were recently demonstrated on chromaffin cells, pointing towards a role of the adrenal medulla in the complex regulation of the inflammatory stress response [40].

In general, the exocytotic secretion of vesicular contents of adrenomedullary chromaffin cells can be achieved via regulated and constitutive secretory pathways. The regulated secretory pathway provides the principle mechanism responsible for controlled release of catecholamines and is calcium-dependent and responsive to both neuronal and non-neuronal input. In contrast, the constitutive secretory pathway, which is calcium-independent, is mainly unresponsive to neuronal and non-neuronal input. The principal function of the constitutive secretory pathway is thought to be the transport of proteins and macromolecules to the cell surface for purposes of membrane maintenance and support of the extracellular matrix. In addition, this pathway may also contribute to basal release of catecholamines (Figure 2) [145,169].

\subsubsection{Neuronal Regulation of the Calcium-Dependent Catecholamine Secretory Pathway}

In recent years, considerable progress has been made in unravelling the complex molecular background and the functional elements of the highly regulated exocytotic machinery in 
adrenomedullary chromaffin cells (Figure 2) $[145,171,172]$. Release of acetylcholine by the splanchnic nerve activates the nicotinic receptor on chromaffin cells, resulting in opening of the ionophoric part of the receptor protein, thereby allowing the entry of extracellular sodium $\left(\mathrm{Na}^{+}\right)$and calcium $\left(\mathrm{Ca}^{2+}\right)$. This generates a small membrane depolarization, resulting in the opening of voltage dependent $\mathrm{Na}^{+}$ channels. The subsequent $\mathrm{Na}^{+}$influx results in a large membrane depolarization, which opens various types of voltage dependent $\mathrm{Ca}^{2+}$ channels [167].

The distribution of the different calcium channel subtypes is species specific. The P/Q-type calcium channel predominates in human adrenomedullary chromaffin cells $[167,171,172]$. As a consequence of elevated intracellular $\mathrm{Ca}^{2+}$ concentrations, the exocytotic machinery and the regulatory components for vesicular exocytosis are activated, which occurs through a pathway consisting of secretory vesicle recruitment, docking, priming, and fusion with the plasma membrane. Priming is the process in which secretory vesicles become fusion competent $[167,172]$. First, $\mathrm{Ca}^{2+}$ influx leads to dismantling of the cortical actin cytoskeleton of the chromaffin cell, a dynamic network of numerous cytoplasmic proteins located on the inner face of the chromaffin cell membrane [173]. Although this can be activated without $\mathrm{Ca}^{2+}$, this is mainly an ATP and a $\mathrm{Ca}^{2+}$ dependent step, as are recruitment, tethering, and docking of the vesicles.

Fusion, release, and retrieval of vesicles can be triggered by $\mathrm{Ca}^{2+}$ in the absence of ATP $[145,174]$. Various soluble and membrane-bound proteins are involved in the complex protein-protein interactions underlying membrane trafficking and fusion. Key components of this process are $N$-ethylmaleimide soluble factor proteins (soluble cytosolic NSF), soluble NSF attachment proteins (SNAPs), and soluble NSF attachment receptor proteins (SNAREs). The vesicle-associated membrane protein (VAMP or synaptobrevin) and the calcium binding protein synaptotagmin are SNAREs located at the secretory vesicle membrane. The synaptosomal-associated protein 25 (SNAP-25) and syntaxin are SNAREs acting on the chromaffin cell plasma membrane $[145,167,172]$. The complex formed by chromaffin vesicle SNAREs (VAMP, synaptotagmin), the chromaffin cell membrane SNAREs (syntaxin, SNAP-25), and the cytosolic proteins (NSF) is thought to provide the primary molecular machinery responsible for the docking and the fusion of synaptic vesicles at the chromaffin cell plasma membrane (Figure 2) [174]. Furthermore, it is believed that NSF and SNAPs have multiple sites of actions on SNARE proteins. Besides pre-docking actions and their function as molecular chaperones in SNARE priming, they also act on SNAREs post-fusion to facilitate vesicle retrieval and allow recycling of empty vesicles $[145,167,172,174]$.

Apart from NSF, SNAPs, and SNAREs, several other proteins are involved in calcium triggered exocytosis. Proposed candidates are the stabilizing protein Munc18-1, the calcium transducer calmodulin (CALM), the $\mathrm{Ca}^{2+}$ dependent secretion activator (CAPS), rabphilin, and annexins $[169,172,174]$. Rabphilin3A is a small GTP-ase, which acts as a molecular switch, thereby determining the sensitivity of secretory vesicles for docking and fusion. Overexpression of rabphilin3A has been found to inhibit exocytosis in adrenomedullary chromaffin cells and probably protects against spontaneous exocytosis under basal conditions [175]. Annexins have the ability to form cross-links between secretory vesicles and the plasma membrane by a functional interplay with SNAREs during exocytosis $[145,169,176-178]$.

\subsubsection{Non-Neuronal Regulation of Catecholamine Secretion}

Along with catecholamines, the adrenal medulla synthesizes and releases numerous enzymes, peptides, and proteins that exert various trophic and neurotransmitter activities, which provide fine-tuning of catecholamine synthesis and secretion in an autocrine and a paracrine manner $[62-65,101,111,113,117,118,129,157]$ (Table 1). We discuss here in more detail neuropeptide $\mathrm{Y}(\mathrm{NPY})$, adrenomedullin $(\mathrm{AM})$, PACAP, and the secretion-inhibiting peptide catestatin $[101,111,117,118,129]$. These peptides modulate chromaffin cell function through a variety of membrane receptors, the vast majority of which belong to the family of $G$ protein-coupled receptors (GPCRs) [117]. 
Neuropeptide $\mathrm{Y}$ is a 36-amino acid neuropeptide, which is widely and abundantly distributed in the brain and the sympathetic nervous system, including the human adrenal medulla. Several NPY receptors (i.e., Y1, Y2, Y4, and Y5) are expressed in the adrenal gland, indicating that NPY exerts local autocrine effects. It has been shown that NPY is able to stimulate catecholamine secretion by inducing TH expression and increasing intracellular calcium [63,101,117,118,129,179].

Adrenomedullin (AM) is a 52-amino acid peptide originally isolated from a human pheochromocytoma and also is present at high concentrations in the normal adrenal medulla $[101,117,129]$. AM demonstrates autocrine and paracrine effects through binding to the adrenomedullin receptor (ADMR), the receptor dog CDNA (RDC1), and the calcitonin receptor-like receptor (CRLR), which results in augmentation of the adrenal blood flow and stimulation of catecholamine release. In addition, the endocrine effects of AM include systemic vasodilatation and stimulation of natriuresis $[63,101,117,129]$.

As previously mentioned, PACAP not only acts as a neurotransmitter released by the splanchnic nerve but is also co-secreted with catecholamines, exerting its effects by binding to the PACAP-preferring receptor (PAC1-R) and VIP/PACAP receptors (VPAC1-R and VPAC2-R), the former representing the predominant receptor in chromaffin cells (Figure 2) [101,117,129]. PACAP, a neuropeptide of 27 or 38 amino acids, enhances catecholamine secretion by induction of transcription as well as stimulating the activity of the biosynthetic enzymes TH, DBH, and PNMT [101]. In normal adrenal medullary chromaffin cells, PACAP also stimulates the expression and the secretion of several other peptides, such as brain natriuretic peptide, enkephalins, EM66, and secretoneurin, which in turn exert their own individual autocrine/paracrine effects on catecholamine secretion $[40,63,101,117,129,130]$.

Catestatin is a biologically active peptide fragment derived from proteolytic chromogranin A cleavage [63]. Catestatin acts mainly as a noncompetitive nicotinic cholinergic antagonist, thus providing a strong negative feedback inhibition of catecholamine secretion [111,112].

\section{Pheochromocytoma and Paraganglioma}

From a genetic perspective, pheochromocytomas and paragangliomas (PPGL) have one of the richest hereditary backgrounds among all neoplasms. At least 35-perhaps up to $40 \%$ - of all PPGL harbor a germline pathogenic variant in one of the several susceptibility genes [180-184]. Initial gene expression profiling studies by Dahia et al. in 2005 [185] revealed two cluster groups, designated cluster 1 and cluster 2, that reflected respective activation of pseudohypoxia and kinase signaling pathways. Those different gene expression signatures matched closely to those reported in an earlier study for norepinephrine- versus epinephrine-producing sporadic tumors and tumors from patients with von-Hippel Lindau (VHL) syndrome and multiple endocrine neoplasia type 2 (MEN2) [186]. The molecular characterization from The Cancer Genome Atlas (TCGA) project has more recently provided a sophisticated molecular taxonomy of PPGL, which divides these neuroendocrine tumors into groups with similar pathogenesis and molecular biology and provides an up-to-date framework (Figure 3) [187-189]. The recent identification of newly recognized somatic mutations in the driver genes, Cold shock domain-containing E1 (CSDE1) and Mastermind-like transcriptional coactivator 3 (MAML3), could add a third cluster-i.e., the Wnt altered group [187] — to the original classification of Dahia et al. of 2005 [185]. This cluster 3 is associated with an abnormal activation of the Wnt-signaling pathway.

Cluster 1, the pseudohypoxia group, can be subdivided into a tricarboxylic acid (TCA) cycleand a VHL/EPAS1 related group. The TCA cycle-related subgroup consists of germline pathogenic variants in genes encoding fumarate hydratase $(F H)$ or one of the succinate dehydrogenase $(S D H)$ subunits A, B, C, D, or the complex assembly factor 2 (AF2). Germline pathogenic variants in Malate Dehydrogenase $2(\mathrm{MDH} 2)$ and somatic mutations in Isocitrate Dehydrogenase type 2 (IDH2) genes also can be categorized in this subgroup [190,191]. The VHL/EPAS1-related subgroup consists of germline and somatic pathogenic variants in the genes VHL and EPAS1 [encoding the hypoxia inducible factor $2 \alpha(\mathrm{HIF} 2 \alpha)$ protein] [192]. In addition, it was proposed that mutations in genes encoding prolyl 
hydroxylase 1 (PHD1, also known as egl nine homolog 2; EGLN2) and iron regulatory protein 1 (IRP1) should also be considered as members of this subgroup [193].

\begin{tabular}{|c|c|c|c|}
\hline \multicolumn{2}{|c|}{$\begin{array}{l}\text { Pseudohypoxia } \\
\text { 15-20\% PPGL }\end{array}$} & $\begin{array}{l}\text { Wnt signaling } \\
\text { 5-10\% PPGL }\end{array}$ & $\begin{array}{l}\text { Kinase signaling } \\
50-60 \% \text { PPGL }\end{array}$ \\
\hline \multicolumn{2}{|l|}{ Driver genes } & Driver genes & Driver genes \\
\hline $\begin{array}{l}\text { TCA cycle + } \\
\text { Germline } 100 \% \\
\text { FH, MDH2, } \\
\text { SDHx }\end{array}$ & $\begin{array}{l}\text { TCA cycle - } \\
\text { Germline } 25 \% \\
\text { VHL, PHD1, } \\
\text { IRP1, EPAS1 }\end{array}$ & $\begin{array}{l}\text { Germline 0\% } \\
\text { CSDE1, MAML3 }\end{array}$ & $\begin{array}{l}\text { Germline } 20 \% \\
\text { RET, NF1, MAX, TMEM127, HRAS }\end{array}$ \\
\hline \multicolumn{2}{|l|}{ Biochemical } & Biochemical & Biochemical \\
\hline $\begin{array}{l}\text { NE DA } \\
\text { NMN/3-MT } \\
\text { VMAT high } \\
\text { no PNMT }\end{array}$ & $\begin{array}{l}\text { NE } \\
\text { NMN } \\
\text { VMAT high } \\
\text { no PNMT }\end{array}$ & $\begin{array}{l}\text { NE (E) } \\
\text { NMN/MN } \\
\text { VMAT low } \\
\text { PNMT low }\end{array}$ & $\begin{array}{l}\text { E } \\
\text { NMN/MN } \\
\text { PNMT high }\end{array}$ \\
\hline \multicolumn{2}{|l|}{ Location } & Location & Location \\
\hline \multicolumn{2}{|c|}{ Adrenal, extra-adrenal } & Adrenal & Adrenal \\
\hline \multicolumn{2}{|c|}{ Chromaffin cell type } & Chromaffin cell type & Chromaffin cell type \\
\hline \multicolumn{2}{|c|}{$\begin{array}{l}\text { Immature, dedifferentiated } \\
\text { exocytotic machinery }\end{array}$} & Intermediate & $\begin{array}{l}\text { Mature, differentiated exocytotic } \\
\text { machinery }\end{array}$ \\
\hline \multicolumn{2}{|c|}{ Signs and symptoms } & Signs and symptoms & Signs and symptoms \\
\hline \multicolumn{2}{|c|}{$\begin{array}{l}\text { Sustained } \mathrm{HT} \text {, constipation, } \\
\text { sweating, headache }\end{array}$} & Mixed & $\begin{array}{l}\text { Paroxysmal HT, flushing, } \\
\text { palpitations }\end{array}$ \\
\hline \multicolumn{2}{|c|}{ Secretory pathway } & Secretory pathway & Secretory pathway \\
\hline \multicolumn{2}{|c|}{ Constitutive pathway } & Not known & Regulatory pathway \\
\hline \multicolumn{2}{|c|}{ Metastatic disease risk } & Metastatic disease risk & Metastatic disease risk \\
\hline \multicolumn{2}{|l|}{+} & $+/-$ & - \\
\hline \multicolumn{2}{|c|}{ Future diagnostic options } & Future diagnostic options & Future diagnostic options \\
\hline \multicolumn{2}{|c|}{$\begin{array}{l}\text { Metabolic profiling } \\
\text { Hypoxia imaging }\end{array}$} & Not known & Not known \\
\hline \multicolumn{2}{|c|}{ Future treatment options } & Future treatment options & Future treatment options \\
\hline \multicolumn{2}{|c|}{$\begin{array}{l}\text { Methylome: } \\
\text { TCA-cycle + = hypermethylation: } \\
\text { demyelination } \\
\text { azacytidine/decitabine }\end{array}$} & Not known & $\begin{array}{l}\text { Influencing kinase pathway: } \\
\text { RET1: Tyrosine kinase inhibitors } \\
\text { NF1: MEK inhibitors }\end{array}$ \\
\hline \multicolumn{4}{|c|}{$\begin{array}{l}\text { TCA-cycle + glutaminase inhibitor } \\
\text { (phase l) }\end{array}$} \\
\hline \multicolumn{4}{|c|}{$\begin{array}{l}\text { HIF } 1 \alpha / 2 \alpha \text { inhibitors and VEGF } \\
\text { inhibition }\end{array}$} \\
\hline \multicolumn{4}{|c|}{$\begin{array}{l}\text { Receptor targeted therapy: } \\
\text { SDHx: peptide receptor } \\
\text { radionuclide therapy }{ }^{80} \mathrm{Y} \text { or } \\
1{ }^{17} \mathrm{LU} \text { somatostatin analogue } \\
\text { (DOTATATE): targeted cytotoxic }\end{array}$} \\
\hline
\end{tabular}

Figure 3. The Pseudohypoxia group (cluster I) divided into two subgroups: tricarboxylic acid (TCA) cycle related, containing germline pathogenic variants in succinate dehydrogenase subunits SDHA, $S D H B, S D H C$, and $S D H D$ as well as SDHAF2 $(S D H x)$, assembly factor for the succinate dehydrogenase 
complex, and $F H$, a second enzyme in the tricarboxylic acid (TCA) cycle. The second subgroup: VHL/EPAS1-related with somatic and germline pathogenic variants. Pathogenic variants in three additional genes encoding for malate dehydrogenase 2 ( $M D H 2$ ), prolyl hydroxylase 1 (PHD1, also known as egl nine homolog 2; EGLN2), and iron regulatory protein 1 (IRP1) were not included previously in the molecular classification by TCGA but were recently discovered. Based on their signaling pathways, it is believed that these new genes should be included as part of the cluster I pseudohypoxia group because $M D H 2$ is part of to the TCA cycle and both PDH1 and IRP1 belong to the VHL/EPAS1 related subgroup. Cluster I is characterized by the expression of genes involved in the "hypoxic response", resulting in a "pseudo-hypoxic" phenotype with uncontrolled expression of HIF1 $\alpha$ regulated genes such as VEGF. HIF1 $\alpha$ regulates the transcription of genes associated with tumorigenesis and angiogenesis. Wnt altered signaling group (cluster III) consists of newly recognized somatic mutations in CSDE1 as well as somatic gene fusions affecting MAML3. This group exclusively consists of somatic mutations that activate the Wnt pathway, which is not activated under normal conditions. Wnt signaling and therefore increased expression of $\beta$-catenin is associated with a poorer prognosis and a higher metastatic potential of tumors. There is still much unknown about this group. Kinase signaling group (Cluster II) consists of germline or somatic pathogenic variants in the driver genes RET, NF1, TMEM127, MAX, and HRAS. This cluster is characterized by an increased activation of the MAP kinase and the P13K/AKT pathways, which results in an increased expression of genes involved in protein synthesis, kinase signaling, endocytosis, and preservation of differentiated/mature chromaffin cell catecholamine biosynthetic machinery. MAX mutated tumors are an exception, since they show an intermediate catecholamine biochemical phenotype with detectable expression of PNMT and some production of epinephrine. MAX is a distinct sub-cluster of the kinase signaling group and was recently proposed to be possibly redivided in a new group, the cortical admixture group [187-189,193].

Cluster 2 related mutations are associated with abnormal kinase signaling pathways and include germline or somatic pathogenic variants in genes encoding for rearranged-during-transfection (RET), neurofibromin (NF1), transmembrane protein 127 (TMEM127), MYC-associated factor X (MAX), and Harvey rat sarcoma proto-oncogene (H-RAS) [193,194].

Each of these clusters is associated with unique downstream signaling pathways, which correspond to certain clinical features and offer potential targets for future diagnostic, therapeutic, and prognostic purposes (Figure 3).

The hallmark of pheochromocytomas and sympathetic paragangliomas is their ability to secrete catecholamines in an uncontrolled fashion compared to normal adrenomedullary chromaffin cells. Unlike normal adrenomedullary chromaffin cells, chromaffin tumor cells are not innervated, and catecholamine secretion is therefore not stimulated by the previously described neuronal stimuli [195]. Theoretically, and as discussed below, the hypersecretion of catecholamines could be explained by various perturbations of the molecular machinery involved in their biosynthesis, secretion, and metabolism.

\subsection{Increased Biosynthesis of Catecholamines}

The most obvious explanation for the hypersecretion of catecholamines by pheochromocytomas is the increased number of cells able to produce and secrete catecholamines. There are limited data on the tissue concentration of catecholamines in normal adrenal medulla as compared with pheochromocytoma, demonstrating either no difference or a higher content of epinephrine in the latter [88,195]. At the cellular level, there is evidence of an upregulation of expression and activity of the biosynthetic enzymes. In particular, Jarrot et al. [89] described in 1977 that the activity of $\mathrm{TH}, \mathrm{AADC}$, and DBH was enhanced in human pheochromocytoma compared to normal human adrenal medulla tissue specimens. These early observations were subsequently supported by several immunohistochemical studies [196-201].

Isobe et al. demonstrated that pheochromocytoma cells contained increased levels of mRNA encoding $T H, A A D C$, and $D B H$ compared to normal adrenal medulla [88]. They also found 
a strong positive correlation between $\mathrm{TH}$ mRNA concentration and total catecholamine content in pheochromocytomas that was absent in normal adrenal medulla tissue. Moreover, they found lower concentrations of PNMT mRNA in pheochromocytoma compared to normal adrenal medulla [88], which might be explained, in part, by lower concentrations of cortisol reaching tumor tissues [88,202]. Of interest, Kimura et al. [196] demonstrated that PNMT immunoreactivity was limited to the mixed epinephrine and norepinephrine producing pheochromocytomas, and tumor cells with PNMT tended to be located close to the adrenal cortex.

All above referenced studies involving comparisons of pheochromocytoma tissue with normal adrenal medulla must be interpreted cautiously since it is difficult to isolate normal adrenal medullary from cortical tissue and thereby establish true differences between normal and tumor cells [203]. What is clear is that catecholamine contents of pheochromocytoma or paraganglioma tumor tissue are highly variable, both in terms of total amounts and relative content of norepinephrine and epinephrine [195,199,204]. Most tumors produce relatively low amounts of dopamine, but there are exceptions, usually isolated paragangliomas presumably lacking significant expression of DBH [205-207].

\subsubsection{Relationship between Genotype and Catecholamine Biochemical Phenotype}

Mutation-dependent differentiation of the chromaffin progenitor cells influences the expression of the biosynthetic enzymes, which leads to distinct phenotypic features of the tumors [206]. Three biochemical phenotypes can be distinguished, i.e., noradrenergic, adrenergic, and dopaminergic, based on the main catecholamines that are produced. Typical pheochromocytomas produce both norepinephrine and epinephrine in variable proportions. A small subset of PPGL is biochemically silent, and almost all of these are paragangliomas [208,209].

The two gene expression clusters (cluster 1 and 2) described earlier are not only characterized by distinct patterns of gene activation but also distinct catecholamine biochemical phenotypes $[186,207,210]$. Cluster 2 tumors due to somatic and/or germline NF1, RET, TMEM127, MAX, and HRAS pathogenic variants, which are characterized by activated kinase and protein translation signaling pathways, almost always originate in the adrenals and produce epinephrine due to expression of PNMT. They have more mature catecholamine secretory pathways and phenotypic features $[186,207,210]$ and also tend to develop later in life than tumors due to cluster 1 mutations.

In contrast, cluster 1 tumors with the pseudohypoxic phenotype due to germline pathogenic variants of $V H L, S D H x, F H$, and somatic mutations of EPAS1 (HIF2 $\alpha$ ) occur with variable frequencies at extra-adrenal or adrenal locations and show negligible epinephrine production due to near absent expression of PNMT $[186,187,207,210]$. This is also independent of their adrenal or extra-adrenal locations due to hypermethylation of the PNMT promoter [211]. The underlying pseudohypoxic phenotype of cluster 1 tumors is due to HIF stabilization, and it appears that it is the stabilization of HIF $2 \alpha$ that is more important than that of HIF1 $\alpha$ for the distinct phenotypic features of cluster 1 compared to cluster 2 chromaffin cell tumors [186,212-215]. Indeed, HIF2 $\alpha$ was identified in 2004 as a key differentially expressed gene, which is more highly expressed in noradrenergic tumors compared to adrenergic tumors, where its expression is essentially absent [186]. Mechanistic studies by Qin et al. [215] showed that expression and the stabilization of HIF2 $\alpha$ in chromaffin cells that normally expressed PNMT and produced epinephrine resulted in complete suppression of steroid-induced induction of PNMT. Since HIF2 $\alpha$ is expressed transiently in chromaffin progenitors during embryogenesis [216-218], it is possible that HIF $2 \alpha$ stabilization may promote a noradrenergic rather than an adrenergic phenotype. This concept is supported by findings that transgenic mice with mutations that stabilize HIF $2 \alpha$ are characterized by adrenals that express less PNMT and produce more norepinephrine than epinephrine compared to adrenals of wild type mice [219].

Thus, it seems that cluster 1 adrenal tumors arise from chromaffin progenitors in which both transcriptional expression of HIF2 $\alpha$ and stabilization of the translated HIF2 $\alpha$ protein blocks the effects of steroids produced locally by cortical cells, explaining why these tumors in the end do not produce 
epinephrine. Such influences occurring during embryogenesis could also be responsible for the younger age of presentation of patients with cluster 1 compared to cluster 2 tumors as well as their propensity for a multifocal presentation [211].

The effect of HIF $2 \alpha$ to block steroid induced expression of PNMT and other genes is suggested to involve a mechanism involving the MYC/MAX complex and MYC-mediated control of gene transcription [215]. A role of MAX is indicated by the demonstration that, in rat $\mathrm{PC} 12$ pheochromocytoma cells, which lack a functional MAX gene, re-expression of MAX facilitates return of steroid-induced PNMT expression. In contrast, silencing MAX in pheochromocytoma cells that express PNMT results in attenuated steroid-induced PNMT [215]. This provides a potential point of intersection for almost all upstream tumor susceptibility genes and also explains the catecholamine biochemical phenotype of MAX-mutated pheochromocytomas, which express some PNMT and produce some epinephrine, though in amounts that lie in between cluster 1 and cluster 2 tumors $[207,220]$.

\subsubsection{Relationship between Genotype and Catecholamine Secretory Pathways}

The two distinct genetic clusters seem to be not only associated with differences in biochemical profile but also with variations in secretory processes. For example, data derived from microarrays and proteomics have shown reduced expression of various components of the regulated secretory pathway (e.g., SNAP25, syntaxin, rabphilin 3A, annexin) in VHL-related pheochromocytomas compared to RET-related pheochromocytomas [169]. In addition, the rate constant for baseline catecholamine secretion was found to be 20-fold higher in VHL- than in RET-related pheochromocytoma. Moreover, only in RET-mutated tumors catecholamine, secretion was shown to be responsive to glucagon. These observations suggest that catecholamine secretion in VHL-associated pheochromocytomas exhibits more constitutive-like continuous secretory characteristics, whereas in RET-associated pheochromocytomas, secretion still is constrained by expression of many components of the regulated secretory pathway. Thus, differences in the molecular machinery underlying catecholamine exocytosis may explain the more paroxysmal nature of symptoms and signs in patients with MEN2 as compared to those with the VHL syndrome. In addition, it was demonstrated that the expression of VMAT1 mRNA was significantly higher in pheochromocytomas from VHL compared to MEN2 patients $[164,189]$. In addition, higher levels of VMAT1 correlated with lower tumor tissue contents of catecholamines and lower numbers of catecholamine containing vesicles, which likely reflects the higher turnover of catecholamines in noradrenergic VHL-related compared to adrenergic pheochromocytomas [164].

\subsection{Alterations in Chromaffin Cell Pathways Associated with Metastatic Pheochromocytoma and Paraganglioma}

\subsubsection{Clinical Features and Risk Factors}

The majority of PPGLs are characterized by a benign clinical course. In $10-15 \%$ of cases, however, metastases are present at diagnosis or will develop during follow-up. The most common metastatic sites for chromaffin cell tumors are local lymph nodes, bone, liver, and lung [221]. At the moment, there are no discriminative histopathological features by which the biological behavior of a pheochromocytoma or a paraganglioma can be assessed or predicted reliably [222-225]. Therefore, the most recent WHO Classification of Endocrine Organs states that all chromaffin cell tumors are considered to have metastatic potential for which long-term follow-up of patients is required, even after successful resection of a pheochromocytoma or a paraganglioma [221].

Several clinical risk factors have been identified that confer an increased risk for development of metastatic disease. Large size (in general $>5 \mathrm{~cm}$ ) and extra-adrenal location of the primary tumor are associated with metastatic disease [226-230]. Although representing about $20 \%$ of the chromaffin cell tumors, sympathetic paragangliomas are the primary source for about $60 \%$ of cases with metastatic PPGL [229]. 
Germline pathogenic variants of the $S D H B$ gene are present in a relatively high frequency of 8-10\% in patients with a PPGL [184]. Large cohort studies targeted at the genotype-phenotype relationship have shown that, in particular carriers of an $S D H B$ germline, pathogenic variants have an increased risk of metastatic PPGL [184,230-232]. Typical SDHB related PPGLs occur at a younger age and arise more frequently in extra-adrenal locations [233]. A possible increased predisposition to metastatic disease has been suggested for rare germline pathogenic variants in FH [234], SLC25A11 [235], SDHA, and TMEM127 [236], although the number of cases is quite low, making the association difficult to confirm.

In addition to size and location of the PPGL and the presence of certain germline mutations, the risk of metastatic disease is also increased in association with certain alterations in the biochemical profile [237]. In particular, plasma concentrations of dopamine and its metabolite 3-methoxytyramine are significantly higher in patients with metastatic PPGL compared to those with non-metastatic disease $[237,238]$. Most patients with metastatic PPGLs demonstrate a noradrenergic profile with elevated plasma levels of both norepinephrine and normetanephrine, with concomitant lack of or negligible relative increases in plasma concentrations of epinephrine and metanephrine compared to subjects without metastatic disease $[237,239]$. In a relatively large series of patients with metastatic PPGL, only a minority (11\%) of patients had an adrenergic phenotype. Of note, none of these patients had a SDHB-related pheochromocytoma or paraganglioma [240]. The biochemical profile has also been linked to prognosis, as it was shown that patients with elevated plasma levels of dopamine and norepinephrine had a faster progression of their disease [239].

\subsubsection{Molecular Alterations in SDHx-Related PPGL and Their Effect on Catecholamine Biosynthesis}

The SDH complex is a hetero-tetrameric mitochondrial enzyme that consists of two catalytic subunits (SDHA and SDHB) and two membrane-anchoring subunits (SDHC and SDHD). SDH catalyzes the oxidation of succinate to fumarate in the TCA cycle and transfers electrons to the ubiquinone (coenzyme Q) pool in the respiratory chain. SDH assembly factor (SDHAF) is required for the flavination of SDHA, an essential step in formation of the SDH complex.

SDH deficiency leads to the accumulation of succinate, which has structural similarity to 2-ketoglutarate. Succinate is therefore able to act as a competitive inhibitor of 2-ketogluarate-dependent dioxygenases, which include prolyl hydroxylase domain proteins (PHDs), ten-eleven translocation (TET) enzymes, and jumonji-domain histone demethylases (JmjC) demethylases [241,242]. This results in hypermethylation of $\mathrm{CPG}$ (cytosine preceding guanine) islands, regions within the genome that are common in promoter sites rich in CpG dinucleotides. Succinate is a typical example of an oncometabolite, a metabolite that abnormally accumulates in cancer cells as a result of a defective gene encoding the corresponding enzyme, thereby modifying signaling pathways and epigenetic regulation mechanisms. In the study by Letouzé et al. [211], the level of hypermethylation was significantly higher in SDHB compared to other $S D H x$ mutated tumors. Of interest, it was shown that succinate:fumarate ratios were higher in tumor tissue derived from patients with a $S D H B$ pathogenic variant as compared from those with a $S D H C / D$ pathogenic variant [243]. This suggests that functional activity of the SDH complex is most disrupted in the case of mutations of the SDHB subunit, resulting in higher intracellular concentrations of oncometabolites and a concurrent higher metastatic risk.

PHDs are involved in the inactivation of the HIF, a heterodimer that consists of two subunits, one $\alpha$ subunit and one $\beta$ subunit. There are two different $\alpha$-subunits (HIF1 $\alpha$ and HIF $2 \alpha$ ) and two different $\beta$ subunits (HIF1 $\beta$ and aryl hydrocarbon receptor nuclear translocator ARNT2). The $\beta$ subunits are constitutively expressed, whereas HIF1 $\alpha$ and HIF $2 \alpha$ are inactivated in the presence of oxygen through hydroxylation by PHDs and subsequent degradation by the VHL-ubiquitination complex (pVHL). The hydroxylation reaction performed by the PHDs requires oxygen and $\alpha$-ketoglutarate as substrates as well as iron and ascorbate as cofactors [244].

Thus, PHD is inactive in the presence of hypoxia, resulting in stabilization of HIF $\alpha$. The unmodified $\mathrm{HIF} \alpha$ molecule translocates to the nucleus, where it forms a transcriptionally active heterodimer 
together with a HIF $\beta$ subunit, which is able to stimulate various target genes involved in angiogenesis, energy metabolism, and cell survival.

The epigenetic modifications are thought to play an important role in tumorigenesis by deregulating gene expression of key genes. Methylome analysis of a large PPGL cohort demonstrated a clear hypermethylator phenotype in the $S D H x$-related tumors [211].

Besides the PNMT gene, three other genes involved in the catecholamine pathway were also found to be hypermethylated, i.e., DRD2, NPY, and SLC6A2 [211]. Transcription of DRD2 results in the synthesis of the D2-dopamine receptor, and the SLC6A2 gene or solute carrier family 6, member 2 gene encodes the norepinephrine transporter (NET) responsible for reuptake of norepinephrine into presynaptic nerve terminals.

\subsubsection{Relationship between Other Components of the Exocytotic Machinery and Metastatic Disease}

The co-secreted neuropeptides neuropeptide $Y$, adrenomedullin, and PACAP are overexpressed in pheochromocytomas and stimulate catecholamine release [129]. These neuropeptides have also been implicated in influencing cell survival and tumor growth of PPGLs (Table 1) $[119,120,129]$. High expression levels of the adrenomedullin receptor RDC1 were demonstrated in a small series of metastatic PPGL. Overexpression of the adrenomedullin receptor RDC1 has been described in several cancers and has been found to be associated with invasiveness, survival, proliferation, and neo-angiogenesis [129]. These observations suggest a pathophysiological role of the adrenomedullin receptor RDC1 in metastatic PPGL.

Recently, overexpression of LAT-1, and to a lesser extent of LAT-2, has been demonstrated in pheochromocytoma. Moreover, LAT-1 overexpression was strongly correlated with higher levels of urinary catecholamine excretion. It seems plausible that this enhanced expression of LAT is required to ensure a sufficient supply of tyrosine as substrate for the increased catecholamine synthesis. Of interest, LAT-1 expression has been described as a poor prognostic marker in various malignancies, including lung, pancreas, breast, and hepatocellular cancer [245]. It is currently unknown whether LAT expression has any prognostic value in PPGL [246-249].

Connexins (Cx) are the specialized proteins of gap junctions, and these structures play an important role in cell proliferation and differentiation as well as in carcinogenesis. The connexion family consists of 21 different proteins, and it has been demonstrated that the expression pattern of connexins in pheochromocytomas is different from normal adrenal medulla tissue $[170,250]$. In addition, the expression of Cx50 was lower in metastatic as compared to benign pheochromocytomas [250]. However, data on the association between connexion expression pattern and biological behavior of pheochromocytomas are very limited.

In summary, our understanding of the intracellular molecular intricacies associated with metastatic PPGL has greatly improved in recent years. Although elucidation of these pathways is still incomplete, research of the genome-metabolome-phenotype relationship has already generated exciting and clinically important information of these rare neuro-endocrine tumors.

\section{Conclusions and Future Perspectives}

In conclusion, our increased knowledge of catecholamine synthesis, secretion, and regulation has improved our understanding of chromaffin cell tumorigenesis. Disregulation of these pathways is evident in pheochromocytomas and paragangliomas and varies between the different genomic backgrounds of the tumors. For example, the differences in PNMT, VMAT, RDC1, and LAT1 expression may signify a difference in cellular dedifferentiation, making certain tumors more aggressive. In addition, substances such as neuropeptide Y, PACAP, EM66, bombesin, and connexins might be differentially expressed by benign and metatstatic PPGL. These potential prognostic biomarkers will need to be examined in larger and more broad cohorts of PPGLs and in prospective studies to determine their true potential utility as prognostic markers. Moreover, further studies of chromaffin cell products with an unknown role in PPGL (Table 1) might also reveal clinically useful information. 
Future research will continue to provide novel and relevant information that will enhance our current knowledge with respect to both the physiology and the pathophysiology of the chromaffin cell. To this end, an integrative and translational approach is required by combining clinical information with (epi)genomics, transcriptomics, and metabolomics. Such new information could, for example, elucidate the precise relationship between the net effect of the mixture of substances that are co-secreted with catecholamines and the clinical picture. In addition, it would allow better discrimination between benign and potentially metastatic PPGL at the time of initial diagnosis. Moreover, improved insight into the molecular pathways that drive the transformation of the normal chromaffin cell into the malignant chromaffin cell will also offer novel targets for treatment that hopefully will provide a definitive cure for these rare metastatic neuroendocrine tumors in the future.

Author Contributions: Conceptualization: A.M.A.B., M.N.K., G.E., J.W.M.L.; Writing—original draft preparation: A.M.A.B., M.N.K., G.E.; Writing—review and editing: A.M.A.B., G.E., L.F., A.N.A.v.d.H.-S., T.P.L., I.P.K., J.W.M.L., M.N.K.; Visualization: A.M.A.B., M.N.K., A.N.A.v.d.H.-S.

Funding: This research received no external funding.

Acknowledgments: We are grateful to Anna Siebers for the artwork.

Conflicts of Interest: The authors declare no conflict of interest.

\section{References}

1. Melmed, S.; Polonsky, K.S.; Larsen, P.R.; Kronenberg, H.M. Williams Textbook Endocrinology, 13th ed.; Elsevier: Amsterdam, The Netherlands, 2017; ISBN 978-0-323-29738-7.

2. Eisenhofer, G.; Ehrhart-Bornstein, M.; Bornstein, S. The Adrenal Medulla. Physiology and Pathophysiology. In Handbook of the Autonomic Nervous System in Health and Disease; Bolis, C.L., Govoni, S., Eds.; Marcel Dekker Inc.: New York, NY, USA; Basel, Switzerland, 2003; pp. 185-224.

3. Lenders, J.W.M.; Eisenhofer, G. Pathophysiology and diagnosis of disorder of the adrenal medulla: Focus on pheochromocytoma. Compr. Physiol. 2014, 4, 691-713. [PubMed]

4. Pihlajoki, M.; Dörmer, J.; Cochran, R.S.; Heikinheimo, M.; Wilson, D.B. Adrenocortical zonation, renewal and remodeling. Front. Endocrinol. (Lausanne) 2015, 6. [CrossRef] [PubMed]

5. Lumb, R.; Schwartz, Q. Sympathoadrenal neural crest cells: The known, unknown and forgotten? Dev. Growth Differ. 2015, 57, 146-157. [CrossRef] [PubMed]

6. Wong, D.L. Why is the adrenal adrenergic (review). Endocr. Pathol. 2003, 14, 25-36. [CrossRef]

7. Schinner, S.; Bornstein, S.R. Cortical-chromaffin cell interactions in the adrenal gland. Endocr. Pathol. 2005, 16, 91-98. [CrossRef]

8. Merke, D.P.; Chrousos, G.P.; Eisenhofer, G.; Weise, M.; Keil, M.F.; Rogol, A.D.; van Wyk, J.J.; Bornstein, S.R. Adrenomedullary dysplasia and hypofunction in patients with classic 21-hydroxylase deficiency. N. Engl. J. Med. 2000, 343, 1362-1368. [CrossRef]

9. Haase, M.; Willenberg, H.S.; Bornstein, S.R. Update on the corticomedullary interaction in the adrenal gland. Endocr. Dev. 2011, 20, 28-37.

10. Bornstein, S.R.; Gonzalez-Hernandez, J.A.; Ehrhart-Bornstein, M.; Adler, G.; Scherbaum, W.A. Intimate contact of chromaffin and cortical cells within the human adrenal gland forms the cellular basis for important intraadrenal interactions. J. Clin. Endocrinol. Metab. 1994, 78, 225-232.

11. Eisenhofer, G.; Huynh, T.T.; Hiroi, M.; Pacak, K. Understanding catecholamine metabolism as a guide to the biochemical diagnosis of pheochromocytoma. Rev. Endocr. Metab. Disord. 2001, 2, 297-311. [CrossRef]

12. Tank, A.W.; Lee Wong, D. Peripheral and central effects of circulating catecholamines. Compr. Physiol. 2015. [CrossRef]

13. McCarty, R. Learning about stress: Neuronal, endocrine and behavioural adaptations. Stress 2016, 19, 449-475. [CrossRef] [PubMed]

14. Lenders, J.W.; Eisenhofer, G.; Mannelli, M.; Pacak, K. Phaeochromocytoma. Lancet 2005, 366, 665-675. [CrossRef]

15. McNicol, A.M. Update on tumours of the adrenal cortex, pheochromocytoma and extra-adrenal paraganglioma. Histopathology 2011, 58, 155-168. [CrossRef] [PubMed] 
16. Lam, A.K. Update on adrenal tumours in 2017 World Health Organization (WHO) of endocrine tumours. Endocr. Pathol. 2017, 28, 213-227. [CrossRef] [PubMed]

17. Liao, W.B.; Liu, C.F.; Chiang, C.W.; Kung, C.T.; Lee, C.W. Cardiovascular manifestations of pheochromocytoma. Am. J. Emerg. Med. 2000, 18, 622-625. [CrossRef] [PubMed]

18. Brouwers, F.M.; Lenders, J.W.; Eisenhofer, G.; Pacak, K. Pheochromocytoma as an endocrine emergency. Rev. Endocr. Metab. Disord. 2003, 4, 121-128. [CrossRef] [PubMed]

19. Prejbisz, A.; Lenders, J.W.; Eisenhofer, G.; Januszewicz, A. Mortality associated with phaeochromocytoma. Horm. Metab. Res. 2013, 45, 154-158. [CrossRef] [PubMed]

20. Stolk, R.F.; Bakx, C.; Mulder, J.; Timmers, H.J.; Lenders, J.W. Is the excess cardiovascular morbidity in pheochromocytoma related to blood pressure or to catecholamines? J. Clin. Endocrinol. Metab. 2013, 98, 1100-1106. [CrossRef] [PubMed]

21. Berends, A.M.A.; Buitenwerf, E.; de Krijger, R.R.; Veeger, N.J.G.M.; van der Horst-Schrivers, A.N.A.; Links, T.P.; Kerstens, M.N. Incidence of pheochromocytoma and sympathetic paraganglioma in the Netherlands: A nationwide study and systematic review. Eur. J. Intern. Med. 2018, 51, 68-73. [CrossRef]

22. Eisenhofer, G.; Prejbisz, A.; Peitzsch, M.; Pamporaki, C.; Masjkur, J.; Rogowski-Lehmann, N.; Langton, K.; Tsourdi, E.; Peczkowska, M.; Fliedner, S.; et al. Biochemical diagnosis of chromaffin cell tumours in patients at high and low risk of disease: Plasma versus urinary free or deconjugated O-methylated catecholamine metabolites. Clin. Chem. 2018, 64, 1646-1656. [CrossRef]

23. Bozkurt, M.F.; Virgolini, I.; Balogova, S.; Beheshti, M.; Rubello, D.; Decristoforo, C.; Ambrosini, V.; Kjaer, A.; Delgado-Bolton, R.; Kunikowska, J.; et al. Guideline for PET/CT imaging of neuroendocrine neoplasms with ${ }^{68} \mathrm{Ga}$-DOTA-conjugated somatostatin receptor targeting peptides and ${ }^{18}$ F-DOPA. Eur. J. Nucl. Med. Mol. Imaging 2017, 44, 1588-1601. [CrossRef] [PubMed]

24. Pacak, K. Pheochromocytoma: A catecholamine and oxidative stress disorder. Endocr. Regul. 2011, 45, 65-90. [CrossRef] [PubMed]

25. Eisenhofer, G.; Klink, B.; Richter, S.; Lenders, J.W.M.; Robledo, M. Metabologenomics of pheochromocytoma and paraganglioma: An integrated approach for personalised biochemical and genetic testing. Clin. Biochem. Rev. 2017, 38, 69-100. [PubMed]

26. Gupta, G.; Pacak, K.; AACE Adrenal Scientific Committee. Precision medicine: An update on genotype/biochemical phenotype relationships in pheochromocytoma/paraganglioma patients. Endocr. Pract. 2017, 23, 690-704. [CrossRef]

27. Lehnert, H. Regulation of catecholamine synthesizing enzyme gene expression in human pheochromocytoma. Eur. J. Endocrinol. 1998, 138, 363-367. [CrossRef] [PubMed]

28. Garibotto, G.; Tessari, P.; Verzola, D.; Dertenois, L. The metabolic conversion of phenylalanine into tyrosine in the human kidney: Does it have nutritional implications in renal patients? J. Ren. Nutr. 2002, 12, 8-16. [CrossRef] [PubMed]

29. Koopmans, K.P.; Neels, O.N.; Kema, I.P.; Elsinga, P.H.; Links, T.P.; de Vries, E.G.E.; Jager, P.L. Molecular imaging in neuroendocrine tumours: Molecular uptake mechanisms and clinical results. Crit. Rev. Oncol. Hematol. 2009, 71, 199-213. [CrossRef]

30. Salisbury, T.B.; Arthur, S. The regulation and function of the L-type amino acid transporter 1 (LAT1) in cancer. Int. J. Mol. Sci. 2018, 19, 2373. [CrossRef]

31. Eisenhofer, G.; Rundquist, B.; Aneman, A.; Friberg, P.; Dakak, N.; Kopin, I.J.; Jacobs, M.C.; Lenders, J.W. Regional release and removal of catecholamines and extraneuronal metabolism to metanephrines. J. Clin. Endocrinol. Metab. 1995, 80, 3009-3017.

32. Nagatsu, T.; Levitt, M.; Udenfriend, S. Tyrosine hydroxylase: The initial step in norepinephrine biosynthesis. J. Biol. Chem. 1964, 239, 2910-2917.

33. Wolf, M.E.; LeWitt, P.A.; Bannon, M.J.; Dragovic, L.J.; Kapatos, G. Effect of ageing on tyrosine hydroxylase protein content and the relative number of dopamine nerve terminals in human caudate. J. Neurochem. 1991, 56, 1191-1200. [CrossRef] [PubMed]

34. Nagatsu, T. Tyrosine hydroxylase: Human isoforms, structure and regulation in physiology and pathology. Essays Biochem. 1995, 30, 15-35. [PubMed]

35. Rao, F.; Zhang, K.; Zhang, L.; Rana, B.K.; Wessel, J.; Fung, M.M.; Rodriquez-Flores, J.L.; Taupenot, L.; Ziegler, M.G.; O'Connor, D.T. Human tyrosine hydroxylase natural allelic variation: Influcence on autonomic function and hypertension. Cell. Mol. Neurobiol. 2010, 30, 1391-1394. [CrossRef] 
36. Daubner, S.C.; Le, T.; Wang, S. Tyrosine hydroxylase and regulation of dopamine synthesis. Arch. Biochem. Biophys. 2011, 508, 1-12. [CrossRef] [PubMed]

37. Doskeland, A.P.; Flatmark, T. Ubiquitination of soluble and membrane bound tyrosine hydroxylase and degradation of the soluble form. Eur. J. Biochem. 2002, 269, 1561-1569. [CrossRef] [PubMed]

38. Chen, Y.; Best, J.A.; Nagamoto, K.; Tank, A.W. Regulation of tyrosine hydroxylase gene expression by the $\mathrm{m} 1$ muscarinic acetylcholine receptor in rat pheochromocytoma cells. Mol. Brain Res. 1996, 40, 42-54. [CrossRef]

39. Sabban, E.L.; Kvetnansky, R. Stress-triggered activation of gene expression in catecholaminergic systems: Dynamics of transcriptional events. Trends Neurosci. 2001, 24, 91-98. [CrossRef]

40. Eiden, L.E.; Jiang, S.Z. What's new in endocrinology: The chromaffin cell. Front. Endocrinol. (Lausanne) 2018, 9, 711. [CrossRef]

41. Lee, Y.H.; Gyun, Y.; Moon, J.Y.; Kim, J.S.; Jeong, K.H.; Lee, T.W.; Ihm, C.G.; Lee, S.H. Genetic variations of tyrosine hydroxylase in the pathogenesis of hypertension. Electrolyte Blood Press 2016, 14, 21-26. [CrossRef]

42. Zhu, M.Y.; Juorio, A.V. Aromatic L-amino acid decarboxylase: Biological characterization and functional role. Gen. Pharmacol. 1995, 26, 681-696. [CrossRef]

43. Barth, M.; Serre, V.; Hubert, L.; Chaabouni, Y.; Bahi-Buisson, N.; Cadoudal, M.; Rabier, D.; Tich, S.N.; Ribeiro, M.; Ricquier, D.; et al. Kinetic analyses guide the therapeutic decision in a novel form of moderate aromatic acid decarboxylase deficiency. JIMD Rep. 2012, 3, 25-32. [PubMed]

44. Berends, A.M.A.; Kerstens, M.N.; Bolt, J.W.; Links, T.P.; Korpershoek, E.; de Krijger, R.R.; Walenkamp, A.M.E.; Noordzij, W.; van Etten, B.; Kats-Ugurlu, G.; et al. False-positive findings on 6-[18F]fluor-L-3,4-dihydroxyphenylalanine PET (18F-FDOPA-PET) performed for imaging of neuroendocrine tumors. Eur. J. Endocrinol. 2018, 179, 127-135. [CrossRef] [PubMed]

45. Waymire, J.C.; Haycock, J.W. Lack of regulation of aromatic L-amino acid decarboxylase in intact bovine chromaffin cells. J. Neurochem. 2002, 81, 589-593. [CrossRef] [PubMed]

46. Li, X.M.; Juorio, A.V.; Boulton, A.A. NSD-1015 alters the gene expression of aromatic L-amino acid decarboxylase in rat PC12 pheochromocytoma cells. Neurochem. Res. 1993, 18, 915-919. [CrossRef]

47. Lee, J.J.; Jin, C.M.; Kim, Y.K.; Ryu, S.Y.; Lim, S.C.; Lee, M.K. Effects of anonaine on dopamine biosynthesis and L-dopa induced cytotoxicity in PC12 cells. Molecules 2008, 13, 475-487. [CrossRef]

48. Friedman, S.; Kaufman, S. 3,4-Dihydroxyphenylethylamine $\beta$-hydroxylase. Physical properties, copper content, and role of copper in the catalytic activity. J. Biol. Chem. 1965, 240, 4763-4773.

49. Weinshilboum, R.; Axelrod, J. Serum dopamine-beta-hydroxylase activity. Circ. Res. 1971, $28,307-315$. [CrossRef]

50. Palatini, P. Fumarate is the cause of the apparent ping-pong kinetics of dopamine beta-hydroxylase. Biochem. Int. 1985, 11, 565-572.

51. Wimalasena, K.; Dharmasena, S.; Wimalasena, D.S.; Hughbanks-Wheaton, D.K. Reduction of dopamine beta-monooxygenase. A unified model for apparent negative cooperativity and fumarate activation. J. Biol. Chem. 1996, 271, 26032-26043. [CrossRef]

52. Patak, P.; Willenberg, H.S.; Bornstein, S.R. Vitamin C is an important cofactor for both adrenal cortex and adrenal medulla. Endocr. Res. 2004, 30, 871-875. [CrossRef]

53. Trifaro, J. Molecular biology of the chromaffin cell. Ann. N. Y. Acad. Sci. 2002, 971, 11-18. [CrossRef] [PubMed]

54. Yu, P.H. Phenylethanolamine N-methyltransferase from the brain and adrenal medulla of the rat: A comparison of their properties. Neurochem. Res. 1978, 3, 755-762. [CrossRef] [PubMed]

55. Livett, B.G. Adrenal medullary chromaffin cells in vitro. Physiol. Rev. 1984, 64, 1103-1161. [CrossRef] [PubMed]

56. Wong, D.L.; Lesage, A.; Siddall, B.; Funder, J.W. Glucocorticoid regulation of phenylethanolamine N-methyltransferase in vivo. FASEB J. 1992, 6, 3310-3315. [CrossRef] [PubMed]

57. Wong, D.L.; Siddall, B.J.; Ebert, S.N.; Bell, R.A.; Her, S. Phenylethanolamine N-methyltransferase gene expression: Synergistic activation by Egr-1, AP-2 and the glucocorticoid receptor. Brain Res. Mol. Brain Res. 1998, 61, 154-161. [CrossRef]

58. Ceccatelli, S.; Dagerlind, A.; Schalling, M.; Wikstróm, A.C.; Okret, S.; Gustafsson, J.A.; Goldstein, M.; Hökfelt, T. The glucocorticoid receptor in the adrenal gland is localized in the cytoplasm of adrenaline cells. Acta Physiol. Scand. 1989, 137, 559-560. [CrossRef] [PubMed] 
59. Zuckerman-Levin, N.; Tiosano, D.; Eisenhofer, G.; Bornstein, S.; Hochberg, Z. The importance of adrenocortical glucocorticoids for adrenomedullary and physiological response to stress: A study in isolated glucocorticoid deficiency. J. Clin. Endocrinol. Metab. 2001, 86, 5920-5924. [CrossRef]

60. Kennedy, B.; Bigby, T.D.; Ziegler, M.G. Nonadrenal epinephrine-forming enzymes in humans. Characteristics, distribution, regulation, and relationship to epinephrine levels. J. Clin. Investig. 1995, 95, 2896-2902. [CrossRef] [PubMed]

61. Osuala, K.; Telusma, K.; Khan, S.M.; Wu, S.; Shah, M.; Baker, C.; Alam, S.; Abukenda, I.; Fuentes, A.; Seifein, H.B.; et al. Distinctive left-sided distribution of adrenergic derived cells in the adult mouse heart. PLOS ONE 2011, 6, e22811. [CrossRef]

62. Winkler, H.; Apps, D.K.; Fischer-Colbrie, R. The molecular function of adrenal chromaffin granules: Established facts and unresolved topics. Neuroscience 1986, 18, 261-290. [CrossRef]

63. Crivellato, E.; Nico, B.; Ribatti, D. The chromaffin vesicle: Advances in understanding the composition of a versatile, multifunctional secretory organelle. Anat. Rec. (Hoboken) 2008, 291, 1587-1602. [CrossRef] [PubMed]

64. Estévez-Herrera, J.; González-Santana, A.; Baz-Dávila, R.; Machado, J.D.; Borges, R. The intravesicular cocktail and its role in the regulation of exocytosis. J. Neurochem. 2016, 137, 897-903. [CrossRef] [PubMed]

65. Estevez-Herrera, J.; Pardo, M.R.; Dominguez, N.; Pereda, D.; Machado, J.D.; Borges, R. The role of chromogranins in the secretory pathway. Biomol. Concepts 2013, 4, 605-609. [CrossRef] [PubMed]

66. Kim, T.; Tao-Cheng, J.H.; Eiden, L.E.; Loh, Y.P. Chromogranin A, an "on/off" switch controlling dense-core secretory granule biogenesis. Cell 2001, 106, 499-509. [CrossRef]

67. Stenman, A.; Svahn, F.; Hoijat-Farsangi, M.; Zedenius, J.; Söderkvist, P.; Gimm, O.; Larsson, C.; Juhlin, C.C. Molecular profiling of pheochromocytoma and abdominal paraganglioma stratified by the PASS algorithm reveals chromogranin B as associated with histologic prediction of malignant behavior. Am. J. Surg. Pathol. 2019, 43, 409-421. [CrossRef]

68. Zuber, S.; Wesley, R.; Prodanov, T.; Eisenhofer, G.; Pacak, K.; Kantorovich, V. Clinical utility of chromogranin A in SDHx-related paragangliomas. Eur. J. Clin. Investig. 2014, 44, 365-371. [CrossRef] [PubMed]

69. O'Connor, D.; Deftos, L. Secretion of chromogranin A by peptide producing endocrine neoplasms. N. Engl. J. Med. 1986, 314, 1145-1151. [CrossRef]

70. Hsiao, R.J.; Parmer, R.J.; Takiyyuddin, M.A.; O'Connor, D.T. Chromogranin A storage and secretion: Sensitivity and specificity for the diagnosis of pheochromocytoma. Medicine (Baltimore) 1991, 70, $33-45$. [CrossRef]

71. Stridsberg, M.; Husebye, E.S. Chromogranin A and chromogranin B are sensitive circulating markers for pheochromocytoma. Eur. J. Endocrinol. 1997, 136, 67-73. [CrossRef]

72. Brouwers, F.M.; Gläsker, S.; Nave, A.F.; Vortmeyer, A.O.; Lubensky, I.; Huang, S.; Abu-Asab, M.S.; Eisenhofer, G.; Weil, R.J.; Park, D.M.; et al. Proteomic profiling of von Hippel-Lindau syndrome and multiple endocrine neoplasia type 2 pheochromocytomas reveals different expression of chromogranin B. Endocr. Relat. Cancer 2007, 14, 463-471. [CrossRef]

73. Guillemot, J.; Thouënnon, E.; Guérin, M.; Vallet-Erdtmann, V.; Ravni, A.; Montéro-Hadjadje, M.; Lefebvre, H.; Klein, M.; Muresan, M.; Seidah, N.G.; et al. Differential expression and processing of secretogranin II in relation to the status of pheochromocytoma: Implications for the production of the tumoral marker EM66. J. Mol. Endocrinol. 2012, 48, 115-127. [CrossRef] [PubMed]

74. Huh, Y.H.; Jeon, S.H.; Yoo, S.H. Chromogranin B-induced secretory granule biogenesis: Comparison with the similar role of chromogranin A. J. Biol. Chem. 2003, 278, 40581-40589. [CrossRef] [PubMed]

75. Guillemot, J.; Guerin, M.; Thouënnon, E.; Montero-Hadjadje, M.; Leprince, J.; Lefebvre, H.; Klein, M.; Muresan, M.; Anouar, Y.; Yon, L. Characterization and plasma measurement of the WE-14 peptide in patients with pheochromocytoma. PLoS ONE 2014, 9, e88698. [CrossRef] [PubMed]

76. Cleary, S.; Phillips, J.K.; Huynh, T.T.; Pacak, K.; Elkahloun, A.G.; Barb, J.; Worrell, R.A.; Goldstein, D.S.; Eisenhofer, G. Neuropeptide Y expression in phaeochromocytomas: Relative absence in tumours from patients with von Hippel-Lindau syndrome. J. Endocrinol. 2007, 193, 225-233. [CrossRef] [PubMed]

77. Guillemot, J.; Barbier, L.; Thouënnon, E.; Vallet-Erdtmann, V.; Montero-Hadjadje, M.; Lefebvre, H.; Klein, M.; Muresan, M.; Plouin, P.F.; Sei dah, N.; et al. Expression and processing of the neuroendocrine protein secretogranin II in benign and malignant pheochromocytomas. Ann. N. Y. Acad. Sci. 2006, 107, 527-532. [CrossRef] [PubMed] 
78. Stridsberg, M.; Eriksson, B.; Janson, E.T. Measurement of secretogranins II, III, V and proconvertases $1 / 3$ and 2 in plasma from patients with neuroendocrine tumours. Regul. Pept. 2008, 148, 95-98. [CrossRef] [PubMed]

79. Shimizu, K.; Namimatsu, S.; Kitagawa, W.; Akasu, H.; Takatsu, K.; Sugisaki, Y.; Tanaka, S. Immunohistochemical, biochemical and immunoelectron microscopic analysis of antigenic proteins on neuroendocrine cell tumors using monoclonal antibody HISL-19. J. Nippon. Med. Sch. 2002, 69, 365-372. [CrossRef]

80. Marcinkiewicz, M.; Benjannet, S.; Falgueyret, J.P.; Seidah, N.G.; Schurch, W.; Verdy, M.; Cantin, M.; Chretien, M. Identification and localization of 7B2 protein in human, porcine, and rat thyroid gland and in human medullary carcinoma. Endocrinology 1988, 123, 866-873. [CrossRef]

81. Hacker, G.W.; Bishop, A.E.; Terenghi, G.; Varndell, I.M.; Aghahowa, J.; Pollard, K.; Thurner, J.; Polak, J.M. Multiple peptide production and presence of general markers detected in 12 cases of human pheochromocytoma and in mammalian adrenal glands. Virchows Arch. A Pathol. Anat. Histopathol. 1988, 412, 399-411. [CrossRef]

82. Natori, S.; Iguchi, H.; Ohashi, M.; Nawata, H. Plasma 7B2 (a novel pituitary protein) immunoreactivity concentrations in patients with various endocrine disorders. Endocrinol. Jpn. 1988, 35, 651-654. [CrossRef]

83. Srivastava, A.; Padilla, O.; Fischer-Colbrie, R.; Tischler, A.S.; Dayal, Y. Neuroendocrine secretory protein-55 (NESP-55) expression discriminates pancreatic endocrine tumors and pheochromocytomas from gastrointestinal and pulmonary carcinoids. Am. J. Surg. Pathol. 2004, 28, 1371-1378. [CrossRef] [PubMed]

84. Jakobsen, A.M.; Ahlman, H.; Kolby, L.; Abrahamsson, J.; Fischer-Colbrie, R.; Nilsson, O. NESP55, a novel chromogranin-like peptide, is expressed in endocrine tumours of the pancreas and adrenal medulla but not in ileal carcinoids. Br. J. Cancer 2003, 88, 1746-1754. [CrossRef] [PubMed]

85. Rindi, G.; Licini, L.; Necchi, V.; Bottarelli, L.; Campanini, N.; Azzoni, C.; Favret, M.; Giordano, G.; D'Amato, F.; Brancia, C.; et al. Peptide products of the neurotrophin-inducible gene vgf are produced in human neuroendocrine cells from early development and increase in hyperplasia and neoplasia. J. Clin. Endocrinol. Metab. 2007, 92, 2811-2815. [CrossRef] [PubMed]

86. Salton, S.R. Neurotrophins, growth-factor-regulated genes and the control of energy balance. Mt. Sinai J. Med. 2003, 70, 93-100. [PubMed]

87. Salton, S.R.; Ferri, G.L.; Hahm, S.; Snyder, S.E.; Wilson, A.J.; Possenti, R.; Levi, A. VGF: A novel role for this neuronal and neuroendocrine polypeptide in the regulation of energy balance. Front. Neuroendocr. 2000, 21, 199-219. [CrossRef] [PubMed]

88. Isobe, K.; Nakai, T.; Yukimasa, N.; Nanmoku, T.; Takekoshi, K.; Nomura, F. Expression of mRNA coding for four catecholaminesynthesizing enzymes in human adrenal pheochromocytomas. Eur. J. Endocrinol. 1998, 138, 383-387. [CrossRef] [PubMed]

89. Jarrot, B.; Louis, W.J. Abnormalities in enzymes involved in catecholamine synthesis and catabolism in phaeochromocytoma. Clin. Sci. Mol. Med. 1977, 53, 529-535. [CrossRef]

90. Supek, F.; Supekova, L.; Mandiyan, S.; Pan, Y.C.E.; Nelson, H.; Nelson, N. A novel accessory subunit for vacuolar H1-ATPase from chromaffin granules. J. Biol. Chem. 1994, 269, 24102-24106.

91. Balogh, A.; Cadel, S.; Foulon, T.; Picart, R.; der Garabedian, A.; Rousselet, A.; Tougard, C.; Cohen, P. Aminopeptidase B: A processing enzyme secreted and associated with the plasma membrane of rat pheochromocytoma (PC12) cells. J. Cell Sci. 1998, 111, 161-169.

92. Azaryan, A.V.; Schiller, M.R.; Hook, V.Y. Chromaffin granule aspartic proteinase processes recombinant proopiomelanocortin (POMC). Biochem. Biophys. Res. Commun. 1995, 215, 937-944. [CrossRef]

93. Murthy, S.R.; Pacak, K.; Loh, Y.P. Carboxypeptidase E: Elevated expression correlated with tumor growth and metastasis in pheochromocytomas and other cancers. Cell. Mol. Neurobiol. 2010, 30, 1377-1381. [CrossRef] [PubMed]

94. Murthy, S.R.K.; Dupart, E.; Al-Sweel, N.; Chen, A.; Cawley, N.X.; Loh, Y.P. Carboxypeptidase E promotes cancer cell survival, but inhibits migration and invasion. Cancer Lett. 2013, 341, 204-213. [CrossRef] [PubMed]

95. Yasothornsrikul, S.; Greenbaum, D.; Medzihradszky, K.F.; Toneff, T.; Bundey, R.; Miller, R.; Schilling, B.; Petermann, I.; Dehnert, J.; Logvinova, A.; et al. Cathepsin L in secretory vesicles functions as a prohormone-processing enzyme for production of the enkephalin peptide neurotransmitter. Proc. Natl. Acad. Sci. USA 2003, 100, 9590-9595. [CrossRef] [PubMed] 
96. Funkelstein, L.; Beinfeld, M.; Minokadeh, A.; Zadina, J.; Hook, V. Unique biological function of cathepsin L in secretory vesicles for biosynthesis of neuropeptides. Neuropeptides 2010, 44, 457-466. [CrossRef] [PubMed]

97. Laslop, A.; Weiss, C.; Savaria, D.; Eiter, C.; Tooze, S.A.; Seidah, N.G.; Winkler, H. Proteolytic processing of chromogranin B and secretogranin II by prohormone convertases. J. Neurochem. 1998, 70, 374-383. [CrossRef] [PubMed]

98. Parmer, R.J.; Mahata, M.; Mahata, S.; Sebald, M.T.; O'Connor, D.T.; Miles, L.A. Tissue plasminogen activator $(\mathrm{t}-\mathrm{PA})$ is targeted to the regulated secretory pathway. Catecholamine storage vesicles as a reservoir for the rapid release of t-PA. J. Biol. Chem. 1997, 272, 1976-1982. [CrossRef] [PubMed]

99. Parmer, R.J.; Mahata, M.; Gong, Y.; Mahata, S.K.; Jiang, Q.; O'Connor, D.T.; Xi, X.P.; Miles, L.A. Processing of chromogranin A by plasmin provides a novel mechanism for regulating catecholamine secretion. J. Clin. Investig. 2000, 106, 907-915. [CrossRef] [PubMed]

100. Hwang, S.R.; Bundey, R.; Toneff, T.; Hook, V. Endopin serpin protease inhibitors localize with neuropeptides in secretory vesicles and neuroendocrine tissues. Neuroendocrinology 2009, 89, 210-216. [CrossRef]

101. Thouënnon, E.; Piere, A.; Yon, L.; Anouar, Y. Expression of trophic peptides and their receptors in chromaffin cells and pheochromocytoma. Cell. Mol. Neurobiol. 2010, 30, 1383-1389. [CrossRef]

102. Hu, W.; Shi, L.; Zhou, P.H.; Zhang, X.B. Plasma concentrations of adrenomedullin and atrial and brain natriuretic peptides in patients with adrenal pheochromocytoma. Oncol. Lett. 2015, 10, 3163-3170. [CrossRef]

103. Shimosawa, T.; Fujita, T. Adrenomedullin and its related peptide. Endocr. J. 2005, 52, 1-10. [CrossRef] [PubMed]

104. Zudaire, E.; Martinez, A.; Cuttitta, F. Adrenomedullin and cancer. Regul. Pept. 2003, 112, 175-183. [CrossRef]

105. Morimoto, R.; Satoh, F.; Murakami, O.; Hirose, T.; Totsune, K.; Imai, Y.; Arai, Y.; Suzuki, T.; Sasano, H.; Ito, S.; et al. Expression of adrenomedullin 2/intermedin in human adrenal tumors and attached non-neoplastic adrenal tissues. J. Endocrinol. 2008, 198, 175-183. [CrossRef] [PubMed]

106. Chejfec, G.; Lee, I.; Warren, W.H.; Gould, V.E. Bombesin in human neuroendocrine (NE) neoplasms. Peptides 1985, 6, 107-112. [CrossRef]

107. Bostwick, D.G.; Bensch, K.G. Gastrin releasing peptide in human neuroendocrine tumours. J. Pathol. 1985, 147, 237-244. [CrossRef] [PubMed]

108. Linnoila, R.I.; Lack, E.E.; Steinberg, S.M.; Keiser, H.R. Decreased expression of neuropeptides in malignant paragangliomas: An immunohistochemical study. Hum. Pathol. 1988, 19, 41-50. [CrossRef]

109. Fedorak, I.; Prinz, R.A.; Fiscus, R.R.; Wang, X.; Chaumont, J.; Chejfec, G.; Glisson, S. Plasma calcitonin gene-related peptide and atrial natriuretic peptide levels during resection of pheochromocytoma. Surgery 1991, 110, 1094-1098. [PubMed]

110. Mazzocchi, G.; Musajo, F.G.; Neri, G.; Gottardo, G.; Nussdorfer, G.G. Adrenomedullin stimulates steroid secretion by the isolated perfused rat adrenal gland in situ: Comparison with calcitonin gene-related peptide effects. Peptides 1996, 17, 853-857. [CrossRef]

111. Mahata, S.K.; Mahata, M.; Fung, M.; O'Connor, D.T. Catestatin: A multifunctional peptide from chromogranin A. Regul. Pept. 2010, 162, 33-43. [CrossRef] [PubMed]

112. Mahata, S.K.; O'Connor, D.T.; Mahata, M.; Yoo, S.H.; Taupenot, L.; Wu, H.; Gill, B.M.; Parmer, R.J. Novel autocrine feedback control of catecholamine release. A discrete chromogranin a fragment is a noncompetitive nicotinic cholinergic antagonist. J. Clin. Investig. 1997, 100, 123-133. [CrossRef] [PubMed]

113. Guillemot, J.; Ait-Ali, D.; Turquier, V.; Montero-Hadjadje, M.; Fournier, A.; Vaudry, H.; Anouar, Y.; Yon, L. Involvement of multiple signalling pathways in PACAP induced EM66 secretion from chromaffin cells. Regul. Pept. 2006, 137, 79-88. [CrossRef] [PubMed]

114. Yon, L.; Guillemot, J.; Montero-Hadjadje, M.; Grumolato, L.; Leprince, J.; Lefebvre, H.; Contesse, V.; Plouin, P.F.; Vaudry, H.; Anouar, Y. Identification of the secretogranin II-derived peptide EM66 in pheochromocytomas as a potential marker for discriminating benign versus malignant tumors. J. Clin. Endocrinol. Metab. 2003, 88, 2579-2585. [CrossRef] [PubMed]

115. Babinski, K.; Haddad, P.; Vallerand, D.; McNicoll, N.; De Lean, A.; Ong, H. Natriuretic peptides inhibit nicotine-induced whole-cell currents and catecholamine secretion in bovine chromaffin cells: Evidence for the involvement of the atrial natriuretic factor R2 receptors. J. Neurochem. 1995, 64, 1080-1087. [CrossRef] [PubMed]

116. Suga, S.; Nakao, K.; Mukoyama, M.; Arai, H.; Hosoda, K.; Ogawa, Y.; Imura, H. Characterization of natriuretic peptide receptors in cultured cells. Hypertension 1992, 19, 762-765. [CrossRef] [PubMed] 
117. Lymperopoulos, A.; Brill, A.; McCrink, K.A. GPCRs of adrenal chromaffin cells and catecholamines: The plot thickens. Int. J. Biochem. Cell Biol. 2016, 77, 213-219. [CrossRef]

118. Spinazzi, R.; Andreis, P.G.; Nussdorfer, G. Neuropeptide $Y$ and Y receptors in the autocrine-paracrine regulation of adrenal gland under physiological and pathophysiological conditions (review). Int. J. Mol. Med. 2005, 15, 3-13. [CrossRef]

119. Cavadas, C.; Cefai, D.; Rosmaninho-Salgado, J.; Vieira-Coelho, M.A.; Moura, E.; Busso, N.; Pedrazzini, T.; Grand, D.; Rotman, S.; Waeber, B.; et al. Deletion of the neuropeptide Y (NPY) Y1 receptor gene reveals a regulatory role of NPY on catecholamine synthesis and secretion. Proc. Natl. Acad. Sci. USA 2006, 103, 10497-10502. [CrossRef]

120. Kitlinska, J.; Abe, K.; Kuo, L.; Pons, J.; Yu, M.; Li, L.; Tilan, J.; Everhart, L.; Lee, E.W.; Zukowska, Z.; et al. Differential effects of neuropeptide $\mathrm{Y}$ on the growth and vascularizaton of neural crest-derived tumors. Cancer Res. 2005, 65, 1719-1728. [CrossRef]

121. Helman, L.J.; Cohen, P.S.; Averbuch, S.D.; Cooper, M.J.; Keiser, H.R.; Isreal, M.A. Neuropeptide Y expression distinguishes malignant from benign pheochromocytoma. J. Clin. Oncol. 1989, 7, 1720-1725. [CrossRef]

122. Grouzmann, E.; Comoy, E.; Bohuon, C. Plasma neuropeptide $\mathrm{Y}$ concentration in patients with neuroendocrine tumors. J. Clin. Endocrinol. Metab. 1989, 68, 808-813. [CrossRef]

123. Tischler, A.S.; Lee, Y.C.; Perlman, R.L.; Costopoulos, D.; Slayton, V.W.; Bloom, S.R. Production of "ectopic" vasoactive intestinal peptide-like and Neurotensin-like immunoreactivity in human pheochromocytoma cell cultures. J. Neurosci. 1984, 4, 1398-1404. [CrossRef] [PubMed]

124. Tischler, A.S.; Lee, Y.C.; Slayton, V.W.; Bloom, S.R. Content and release of neurotensin in PC12 pheochromocytoma cell cultures: Modulation by dexamethasone and nerve growth factor. Regul. Pept. 1982, 3, 415-421. [CrossRef]

125. Pellizzari, E.H.; Barontini, M.; Figuerola, M.; Cigorraga, S.B.; Levin, G. Possible autocrine enkephalin regulation of catecholamine release in human pheochromocytoma cells. Life Sci. 2008, 83, 413-420. [CrossRef] [PubMed]

126. Gupta, N.; Bark, S.J.; Lu, W.D.; Taupenot, L.; O'Connor, D.T.; Pevzner, P.; Hook, V. Mass spectrometry based neuropeptidomics of secretory vesicles form human adrenal medullary pheochromocytoma reveals novel peptide products of prohormone processing. J. Proteome Res. 2010, 9, 5065-5075. [CrossRef] [PubMed]

127. Yoshimasa, T.; Nakao, K.; Li, S.; Ikeda, Y.; Suda, M.; Sakamoto, M.; Imura, H. Plasma methionine-enkephalin and leucine-enkephalin in normal subjects and patients with pheochromocytoma. J. Clin. Endocrinol. Metab. 1983, 57, 706-712. [CrossRef] [PubMed]

128. Albillos, A.; Gandia, L.; Michelena, P.; Gilabert, J.A.; del Valle, M.; Carbone, E.; Garcia, A.G. The mechanism of calcium channel facilitation in bovine chromaffin cells. J. Physiol. 1996, 494, 687-695. [CrossRef] [PubMed]

129. Thouënnon, E.; Piere, A.; Tanguy, Y.; Guillemot, J.; Manecka, D.L.; Guérin, M.; Ouafik, L.; Muresan, M.; Klein, M.; Bertherat, J.; et al. Expression of trophic amidated peptides and their receptors in benign and malignant pheochromocytomas: High expression of adrenomedullin RDC1 receptor and implication in tumoral cell survival. Endocr. Relat. Cancer 2010, 17, 637-651. [CrossRef] [PubMed]

130. Smith, C.B.; Eiden, L. Is PACAP the major neurotransmitter for stress transduction at the adrenomedullary synapse? J. Mol. Neurosci. 2012, 48, 403-412. [CrossRef]

131. Turquier, V.; Yon, L.; Grumolato, L.; Alexandre, D.; Fournier, A.; Vaudry, H.; Anouar, Y. Pituitary adenylate cyclase-activating polypeptide stimulates secretoneurin release and secretogranin II gene transcription in bovine adrenochromaffin cells through multiple signalling pathways and increased binding of pre-existing activator protein-1-like transcription factors. Mol. Pharm. 2001, 60, 42-52.

132. Fischer-Colbrie, R.; Kirchmair, R.; Kahler, C.M.; Wiedermann, C.J.; Saria, A. Secretoneurin: A new player in angiogenesis and chemotaxis linking nerves, blood vessels and the immune system. Curr. Protein Pept. Sci. 2005, 6, 373-385. [CrossRef] [PubMed]

133. Wiedermann, C.J. Secretoneurin: A functional neuropeptide in health and disease. Peptides 2000, 21, 1289-1298. [CrossRef]

134. Unsicker, K.; Krieglstein, K. Growth factors in chromaffin cells. Prog. Neurobiol. 1996, 48, 307-324. [CrossRef]

135. Combs, S.E.; Ernsberger, U.; Krieglstein, K.; Unsicker, K. Reduction of endogenous TGF-B does not affect phenotypic development of sympathoadrenal progenitors into adrenal chromaffin cells. Mech. Dev. 2001, 109, 295-302. [CrossRef] 
136. Flanders, K.C.; Lüdecke, G.; Engels, S.; Cissel, D.S.; Roberts, A.B.; Kondaiah, P.; Lafyatis, R.; Sporn, M.B.; Unsicker, K. Localization and actions of transforming growth factor-Bs in the embryonic nervous system. Development 1991, 113, 183-191. [PubMed]

137. Lugardon, K.; Raffner, R.; Goumon, Y.; Corti, A.; Delmas, A.; Bulet, P.; Aunis, D.; Metz-Boutigue, M.H. Antibacterial and antifungal activities of vasostatin-1, the N-terminal fragment of chromogranin A. J. Biol. Chem. 2000, 275, 10745-10753. [CrossRef] [PubMed]

138. Russell, J.; Gee, P.; Liu, S.M.; Angeletti, R.H. Inhibition of parathyroid hormone secretion by amino-terminal chromogranin peptides. Endocrinology 1994, 135, 227-342. [CrossRef]

139. Aardal, S.; Helle, K.B. The vasoinhibitory activity of bovine chromogranin A fragment (vasostatin) and its independence of extracellular calcium in isolated segments of human blood vessels. Regul. Pept. 1992, 41, 9-18. [CrossRef]

140. Strub, J.M.; Goumon, Y.; Lugardon, K.; Capon, C.; Lopez, M.; Moniatte, M.; van Dorsselaer, A.; Aunis, D.; Metz-Boutigue, M.H. Antibacterial activity of glycosylated and phosphorylated chromogranin-A derived peptide 173-184 from bovine adrenal medullary chromaffin granules. J. Biol. Chem. 1996, 271, 28533-28540. [CrossRef]

141. Strub, J.M.; Garcia-Sablone, P.; Lonning, K.; Taupenot, L.; Hubert, P.; Van Dorsselaer, A.; Aunis, D.; Metz-Boutigue, M.H. Processing of chromogranin B in bovine adrenal medulla. Identification of secretolytin, the endogenous C-terminal fragment of residues 614-626 with antibacterial activity. Eur. J. Biochem. 1995, 229, 356-368. [CrossRef]

142. Metz-Boutigue, M.H.; Kieffer, A.E.; Goumon, Y.; Aunis, D. Innate immunity: Involvement of new neuropeptides. Trends Microbiol. 2003, 11, 585-592. [CrossRef]

143. Levine, E.Y.; Levenberg, B.; Kaufman, S. The enzymatic conversion of 3,4-dihydroxyphenylethylamine to norepinephrine. J. Biol. Chem. 1960, 235, 2080-2086.

144. Schlüter, H.; Meissner, M.; van der Giet, M.; Tepel, M.; Bachmann, J.; Gross, I.; Nordhoff, E.; Karas, M.; Spieker, C.; Witzel, H.; et al. Coenzyme A glutathione disulfide. A potent vasoconstrictor derived from the adrenal gland. Circ. Res. 1995, 76, 675-680. [CrossRef]

145. Burgoyne, R.D.; Morgan, A. Secretory granule exocytosis. Physiol. Rev. 2003, 83, 581-632. [CrossRef] [PubMed]

146. Tadros, T.S.; Strauss, R.M.; Cohen, C.; Gal, A.A. Galanin immunoreactivity in paragangliomas but not in carcinoid tumors. Appl. Immunohistochem. Mol. Morphol. 2003, 11, 250-252. [CrossRef]

147. Bauer, F.E.; Hacker, G.W.; Terenghi, G.; Adrian, T.E.; Polak, J.M.; Bloom, S.R. Localization and molecular forms of galanin in human adrenals: Elevated levels in pheochromocytomas. J. Clin. Endocrinol. Metab. 1986, 63, 1372-1378. [CrossRef] [PubMed]

148. Painter, G.R.; Diliberto, E.J.; Knoth, J. 31P nuclear magnetic resonance study of the metabolic pools of adenosine triphosphate in cultured bovine adrenal medullary chromaffin cells. Proc. Natl. Acad. Sci. USA 1989, 86, 2239-2242. [CrossRef] [PubMed]

149. Sala, F.; Nistri, A.; Criado, M. Nicotinic acetylcholine receptors of adrenal chromaffin cells. Acta Physiol. 2008, 192, 203-212. [CrossRef]

150. Simasko, S.M.; Durkin, J.A.; Weiland, G.A. Effects of substance P on nicotinic acetylcholine receptor function in PC12 cells. J. Neurochem. 1987, 49, 253-260. [CrossRef]

151. Zhou, X.F.; Livett, B.G. Substance P has biphasic effects on catecholamine secretion evoked by electrical stimulation of perfused rat adrenal glands in vitro. J. Auton. Nerv. Syst. 1990, 31, 31-39. [CrossRef]

152. Oehme, P.; Hecht, H.D.; Faulhaber, K.; Nieber, I.; Roske, I.; Rathsack, R. Relationship of substance P to catecholamines, stress and hypertension. J. Cardiovasc. Pharmacol. 1987, 10, 109-111. [CrossRef]

153. Vinik, A.I.; Shapiro, B.; Thompson, N.W. Plasma gut hormone levels in 37 patients with pheochromocytomas. World J. Surg. 1986, 10, 593-604. [CrossRef] [PubMed]

154. Hu, X.; Cao, W.; Zhao, M. Octreotide reverses shock due to vasoactive intestinal peptide-secreting adrenal pheochromocytoma: A case report and review of literature. World J. Clin. Cases 2018, 6, 862-868. [CrossRef] [PubMed]

155. Jiang, J.; Zhang, L.; Wu, Z.; Ai, Z.; Hou, Y.; Lu, Z.; Gao, X. A rare case of watery diarrhea, hypokalemia and achlorhydria syndrome caused by pheochromocytoma. BMC Cancer 2014, 14, 533. [CrossRef] [PubMed] 
156. Leibowitz-Amit, R.; Mete, O.; Asa, S.L.; Ezzat, S.; Joshua, A.M. Malignant pheochromocytoma secreting vasoactive intestinal peptide and response to Sunitinib: A case report and literature review. Endocr. Pr. 2014, 20, e145-e150. [CrossRef] [PubMed]

157. Ghzili, H.; Grumolato, L.; Thouennon, E.; Tanguy, Y.; Turquier, V.; Vaudry, H.; Anouar, Y. Role of PACAP in the physiology and pathology of the sympathoadrenal system. Front. Neuroendocrinol. 2008, 29, 128-141. [CrossRef] [PubMed]

158. Henry, J.P.; Sagne, C.; Bedet, C.; Gasnier, B. The vesicular monoamine transporter: From chromaffin granule to brain. Neurochem. Int. 1998, 32, 227-246. [CrossRef]

159. Wimalasena, K. Vesicular monoamine transporters: Structure-function, pharmacology, and medicinal chemistry. Med. Res. Rev. 2011, 31, 483-519. [CrossRef]

160. Schuldiner, S.; Shirvan, A.; Linial, M. Vesicular neurotransmitter transporters: From bacteria to humans. Physiol. Rev. 1995, 75, 369-392. [CrossRef]

161. Hillarp, N.A.; Hokfelt, B. Evidence of adrenaline and noradrenaline in separate adrenal medullary cells. Acta Physiol. Scand 1953, 30, 55-68. [CrossRef]

162. Carmichael, S.W. The adrenal chromaffin vesicle: An historical perspective. J. Auton. Nerv. Syst. 1983, 7, 7-12. [CrossRef]

163. Eisenhofer, G. The role of neuronal and extraneuronal plasma membrane transporters. Pharmacol. Ther. 2001, 91, 35-62. [CrossRef]

164. Huynh, T.T.; Pacak, K.; Brouwers, F.M.; Abu-Asab, M.S.; Worrel, R.A.; Walther, M.M.; Elkahloun, A.G.; Goldstein, D.S.; Cleary, S.; Eisenhofer, G. Different expression of catecholamine transporters in phaeochromocytomas from patients with von Hippel-Lindau syndrome and multiple endocrine neoplasia type 2. Eur. J. Endocrinol. 2005, 153, 551-563. [CrossRef] [PubMed]

165. Motulsky, H.J.; Insel, P.A. Adrenergic receptors in man: Direct identification, physiologic regulation, and clinical alterations. N. Engl. J. Med. 1982, 307, 18-29. [CrossRef] [PubMed]

166. Guimaraes, S.; Moura, D. Vascular Adrenoceptors: An update. Pharm. Rev. 2001, 53, 319-356. [PubMed]

167. Aunis, D.; Langley, K. Physiological aspects of exocytosis in chromaffin cells of the adrenal medulla. Acta Physiol. Scand 1999, 167, 89-97. [CrossRef] [PubMed]

168. Wong, D.L.; Anderson, L.J.; Tai, T.C. Cholinergic and peptidergic regulation of phenylethanolamine N-methyltransferase gene expression. Ann. N. Y. Acad. Sci. 2002, 971, 19-26. [CrossRef] [PubMed]

169. Eisenhofer, G.; Huynh, T.T.; Elkahloun, A.; Morris, J.C.; Bratslavsky, G.; Linehan, W.M.; Zhuang, Z.; Balgley, B.M.; Lee, C.S.; Manelli, M.; et al. Differential expression of the regulated catecholamine secretory pathway in different hereditary forms of pheochromocytoma. Am. J. Physiol. Endocrinol. Metab. 2008, 295, E1223-E1233. [CrossRef] [PubMed]

170. Colomer, C.; Desarmenien, M.G.; Guerineau, N.C. Revisiting the stimulus-secretion coupling in the adrenal medulla: Role of gap junction-mediated intercellular communication. Mol. Neurobiol. 2009, 40, 87-100. [CrossRef] [PubMed]

171. García, A.G.; Garciá-de Diego, A.M.; Gandía, L.; Borges, R.; García-Sancho, J. Calcium signalling and exocytosis in adrenal chromaffin cells. Physiol. Rev. 2006, 86, 1093-1131. [CrossRef] [PubMed]

172. Marengo, F.D.; Cardenas, A.M. How does the stimulus define exocytosis in adrenal chromaffin cells (review). Pflug. Arch. 2018, 470, 155-167. [CrossRef] [PubMed]

173. Trifaro, J.M.; Gasman, S.; Gutierrez, L.M. Cytoskeletal control of vesicle transport and exocytosis in chromaffin cells. Acta Physiol. (Oxf.) 2008, 192, 165-172. [CrossRef] [PubMed]

174. Burgoyne, R.; Morgan, A. Analysis of regulated exocytosis in adrenal chromaffin cells: Insights into NSF/SNAP/SNARE function. BioEssays 1998, 20, 328-335. [CrossRef]

175. Holz, R.W.; Brondyk, W.H.; Senter, R.A.; Kuizon, L.; Macara, I.G. Evidence for the involvement of Rab3A in $\mathrm{Ca}(2+)$-dependent exocytosis from adrenal chromaffin cells. J. Biol. Chem. 1994, 269, 10229-10234. [CrossRef] [PubMed]

176. Burgoyne, R.D.; Morgan, A.; Robinson, I.; Pender, N.; Cheek, T.R. Exocytosis in adrenal chromaffin cells. J. Anat. 1993, 183, 309-314.

177. Umbrecht-Jenck, E.; Demais, V.; Calco, V.; Bailly, Y.; Bader, M.F.; Chasserot-Golaz, S. S100A10 mediated translocation of annexin A2 to SNARE proteins in adrenergic chromaffin cells undergoing exocytosis. Traffic 2010, 11, 958-971. [CrossRef] [PubMed] 
178. Gabel, A.G.; Chasserot-Golaz, S. Annexin A2, an essential partner of the exocytotic process in chromaffin cells. J. Neurochem. 2016, 137, 890-896. [CrossRef] [PubMed]

179. Cavadas, C.; Silva, A.L.P.; Mosimann, F.; Cotrim, M.D.; Ribeiro, C.A.; Brunner, H.R.; Grouzmann, E. NPY regulates catecholamine secretion from human adrenal chromaffin cells. J. Clin. Endocrinol. Metab. 2001, 86, 5956-5963. [CrossRef]

180. Fishbein, L.; Merrill, S.; Fraker, D.L.; Cohen, D.L.; Nathanson, K.L. Inherited mutations in pheochromocytoma and paraganglioma: Why all patients should be offered genetic testing. Ann. Surg. Oncol. 2013, 20, 1440-1450. [CrossRef]

181. Dahia, P.L. Pheochromocytoma and paraganglioma pathogenesis: Learning from genetic heterogeneity. Nat. Rev. Cancer 2014, 14, 108-119. [CrossRef]

182. Crona, J.; Nordling, M.; Maharjan, R.; Granberg, D.; Stålberg, P.; Hellman, P.; Björklund, P. Integrative genetic characterization and phenotype correlations in pheochromocytoma and paraganglioma tumours. PLOS ONE 2014, 9, e86756. [CrossRef]

183. Burnichon, N.; Buffet, A.; Gimenez-Roqueplo, A.P. Pheochromocytoma and paraganglioma: Molecular testing and personalized medicine. Curr. Opin. Oncol. 2016, 28, 5-10. [CrossRef] [PubMed]

184. NGS in PPGL (NGSnPPGL) Study Group; Toledo, R.A.; Burnichon, N.; Cascon, N.; Cascon, A.; Benn, D.E.; Bayley, J.P.; Welander, J.; Tops, C.M.; Firth, H.; et al. Consensus statement on next-generation-sequencing-based diagnostic testing of hereditary phaeochromocytomas and paragangliomas. Nat. Rev. Endocrinol. 2017, 13, 233-247. [CrossRef] [PubMed]

185. Dahia, P.L.; Ross, K.N.; Wright, M.E.; Hayashida, C.Y.; Santagata, S.; Barontini, M.; Kung, A.L.; Sanso, G.; Powers, J.F.; Tischler, A.S.; et al. A HIF1alpha regulatory loop links hypoxia and mitochondrial signals in pheochromocytomas. PLoS Genet. 2005, 1, 72-80. [CrossRef] [PubMed]

186. Eisenhofer, G.; Huynh, T.T.; Pacak, K.; Brouwers, F.M.; Walther, M.M.; Linehan, W.M.; Munson, P.J.; Mannelli, M.; Goldstein, D.S.; Elkahloun, A.G. Distinct gene expression profiles in norepinephrine- and epinephrine- producing hereditary and sporadic pheochromocytomas: Activation of hypoxia-driven angiogenic pathways in von Hippel-Lindau syndrome. Endocr. Relat. Cancer 2004, 11, 897-911. [CrossRef] [PubMed]

187. Fishbein, L.; Leshchiner, I.; Walter, V.; Danilova, L.; Robertson, A.G.; Johnson, A.R.; Lichtenberg, T.M.; Murray, B.A.; Ghayee, H.K.; Else, T.; et al. Comprehensive Molecular Characterization of Pheochromocytoma and Paraganglioma. Cancer Cell 2017, 31, 181-193. [CrossRef] [PubMed]

188. Crona, J.; Taïeb, D.; Pacak, K. New perspectives on pheochromocytoma and paraganglioma: Toward a molecular classification. Endocr. Rev. 2017, 38, 489-515. [CrossRef] [PubMed]

189. Fishbein, L.; Wilkerson, M.D. Chromaffin cell biology: Interferences from the Cancer Genome Atlas. Cell Tissue Res. 2018, 372, 339-346. [CrossRef] [PubMed]

190. Calsina, B.; Curras-Freixes, M.; Buffet, A.; Pons, T.; Contreras, L.; Leton, R.; Comino-Mendez, I.; Remacha, L.; Calatayud, M.; Obispo, B.; et al. Role of MDH2 pathogenic variant in pheochromocytoma and paraganglioma patients. Genet. Med. 2018, 20, 1652-1662. [CrossRef] [PubMed]

191. Richter, S.; Gieldon, L.; Pang, Y.; Peitzsch, M.; Huynh, T.; Leton, R.; Viana, B.; Ercolino, T.; Mangelis, A.; Rapizzi, E.; et al. Metabolome-guided genomics to identify pathogenic variants in isocitrate dehydrogenase, fumarate hydratase, and succinate dehydrogenase genes in pheochromocytoma and paraganglioma. Genet. Med. 2019, 21, 705-717. [CrossRef]

192. Yang, C.; Zhuang, Z.; Fliedner, S.M.; Shankavaram, U.; Sun, M.G.; Bullova, P.; Zhu, R.; Elkahloun, A.G.; Kourlas, P.J.; Merino, M. Germ-line PHD1 and PHD2 mutations detected in patients with pheochromocytoma/paraganglioma-polycythemia. J. Mol. Med. 2015, 93, 93-104. [CrossRef]

193. Alrezk, R.; Suarez, A.; Tena, I.; Pacak, K. Update of pheochromocytoma syndromes: Genetics, biochemical evaluation and imaging. Front. Endocrinol. (Lausanne) 2018, 9, 515. [CrossRef] [PubMed]

194. Crona, J.; Delgado Verdugo, A.; Maharjan, R.; Stålberg, P.; Granberg, D.; Hellman, P.; Björklund, P. Somatic mutations in H-RAS in sporadic pheochromocytoma and paraganglioma identified by exome sequencing. J. Clin. Endocrinol. Metab. 2013, 98, E1266-E1271. [CrossRef] [PubMed]

195. Nakada, T.; Furuta, H.; Katayama, T. Catecholamine metabolism in pheochromocytoma and normal adrenal medullae. J. Urol. 1988, 140, 1348-1351. [CrossRef] 
196. Kimura, N.; Miura, Y.; Nagatsu, I.; Nagura, H. Catecholamine synthesizing enzymes in 70 cases of functioning and non-functioning phaeochromocytoma and extra-adrenal paraganglioma. Virchows Arch. A Pathol. Anat. Histopathol. 1992, 421, 25-32. [CrossRef] [PubMed]

197. Funahashi, H.; Imai, T.; Tanaka, Y.; Tobinaga, J.; Wada, M.; Matsuyama, T.; Tsukamura, K.; Yamada, F.; Takagi, H.; Narita, T.; et al. Discrepancy between PNMT presence and relative lack of adrenaline production in extra-adrenal pheochromocytoma. J. Surg. Oncol. 1994, 57, 196-200. [CrossRef] [PubMed]

198. Meijer, W.G.; Copray, S.C.; Hollema, H.; Kema, I.P.; Zwart, N.; Mantingh-Otter, I.; Links, T.P.; Willemse, P.H.; de Vries, E.G. Catecholamine-synthesizing enzymes in carcinoid tumors and pheochromocytomas. Clin. Chem. 2003, 49, 586-593. [CrossRef]

199. Grouzmann, E.; Tschopp, O.; Triponez, F.; Matter, M.; Bilz, S.; Brändle, M.; Drechser, T.; Sigrist, S.; Zulewski, H.; Henzen, C.; et al. Catecholamine metabolism in paraganglioma and pheochromocytoma: Similar tumors in different sites? PLoS ONE 2015, 10, e0125426. [CrossRef] [PubMed]

200. Konosu-Fukaya, S.; Omata, K.; Tezuka, Y.; Ono, Y.; Aoyama, Y.; Satoh, F.; Fujishima, F.; Sasano, H.; Nakamura, Y. Catecholamine-synthesizing enzymes in pheochromocytoma and extra adrenal paraganglioma. Endocr. Pathol. 2018, 29, 302-309. [CrossRef] [PubMed]

201. Iwase, K.; Nagasaka, A.; Nagatsu, I.; Kikuchi, K.; Nagatsu, T.; Funahashi, H.; Tsujimura, T.; Inagaki, A.; Nakai, A.; Kishikawa, T.; et al. Tyrosine hydroxylase induces cell differentiation of catecholamine biosynthesis in neuroendocrine tumors. J. Endocrinol. Investig. 1994, 17, 235-239. [CrossRef]

202. Feldman, J.M. Phenylethanolamine-N-methyltransferase activity determines the epinephrine concentration of pheochromocytomas. Res. Commun. Chem. Pathol. Pharm. 1981, 34, 389-398. [CrossRef]

203. Fliedner, S.M.; Breza, J.; Kvetnansky, R.; Powers, J.F.; Tischler, A.S.; Wesley, R.; Merino, M.; Lehnert, H.; Pacak, K. Tyrosine hydroxylase, chromogranin A, and steroidogenic acute regulator as markers for successful separation of human adrenal medulla. Cell Tissue Res. 2010, 340, 607-612. [CrossRef] [PubMed]

204. Feldman, J.M.; Blalock, J.A.; Zern, R.T.; Wells, S.A., Jr. The relationship between enzyme activity and the catecholamine content and secretion of pheochromocytomas. J. Clin. Endocrinol. Metab. 1979, 49, 445-451. [CrossRef] [PubMed]

205. Dubois, L.A.; Gray, D.K. Dopamine-secreting pheochromocytomas: In search of a syndrome. World J. Surg. 2005, 29, 909-913. [CrossRef] [PubMed]

206. Eisenhofer, G.; Lenders, J.W.; Timmers, H.; Mannelli, M.; Grebe, S.K.; Hofbauer, L.C.; Bornstein, S.R.; Tiebel, O.; Adams, K.; Bratslavsky, G.; et al. Measurements of plasma Methoxytyramine, normetanephrine, and metanephrine as discriminators of different hereditary forms of pheochromocytoma. Clin. Chem. 2011, 57, 411-420. [CrossRef] [PubMed]

207. Eisenhofer, G.; Pacak, K.; Huynh, T.T.; Qin, N.; Bratslavsky, G.; Linehan, W.M.; Mannelli, M.; Friberg, P.; Timmers, H.J.; Bornstein, S.R.; et al. Catecholamine metabolomics and secretory phenotypes in phaeochromocytoma. Endocr. Relat. Cancer 2011, 18, 97-111. [CrossRef] [PubMed]

208. Timmers, H.J.; Pacak, K.; Huynh, T.T.; Abu-Asab, M.; Tsokos, M.; Merino, M.J.; Baysal, B.E.; Adams, K.T.; Eisenhofer, G. Biochemically silent abdominal paragangliomas in patients with mutations in the succinate dehydrogenase subunit B gene. J. Clin. Endocrinol. Metab. 2008, 93, 4826-4832. [CrossRef]

209. Dreijerink, K.M.A.; Rijken, J.A.; Compaijen, C.J.A.C.; Timmers, H.J.L.M.; van der Horst-Schrivers, A.N.A.; van Leeuwaarde, R.S.; van Dam, S.; Leemans, C.R.; van Dam, E.W.C.M.; Dickhoff, C.; et al. Biochemically silent sympathetic paraganglioma, pheochromocytoma or metastatic disease in SDHD mutation carriers. J. Clin. Endocrinol. Metab. 2019. [CrossRef]

210. Eisenhofer, G.; Walther, M.; Huynh, T.T.; Li, S.T.; Bornstein, S.R.; Vortmeyer, A.; Mannelli, M.; Goldstein, D.S.; Linehan, W.M.; Lenders, J.W.; et al. Pheochromocytomas in von Hippel-Lindau Syndrome and multiple endocrine neoplasia type 2 display distinct biochemical and clinical phenotypes. J. Clin. Endocrinol. Metab. 2001, 86, 1999-2008. [CrossRef]

211. Letouzé, E.; Martinelli, C.; Loriot, C.; Burnichon, N.; Abermil, N.; Ottolenghi, C.; Janin, M.; Menara, M.; Nguyen, A.T.; Benit, P.; et al. SDH mutations establish a hypermethylator phenotype in paraganglioma. Cancer Cell 2013, 23, 739-752. [CrossRef]

212. Favier, J.; Briere, J.J.; Burnichon, N.; Riviere, J.; Vescovo, L.; Benit, P.; Giscos-Douriez, I.; De Reynies, A.; Bertherat, J.; Badoual, C.; et al. The Warburg effect is genetically determined in inherited pheochromocytomas. PLoS ONE 2009, 4, e7094. [CrossRef] 
213. Lopez-Jimenez, E.; Gomez-Lopez, G.; Leandro-Garcia, L.J.; Munoz, I.; Schiavi, F.; Montero-Conde, C.; de Cubas, A.A.; Ramires, R.; Landa, I.; Leskelä, S.; et al. Research resource: Transcriptional profiling reveals different pseudohypoxic signatures in SDHB and VHL-related pheochromocytomas. Mol. Endocrinol. 2010, 24, 2382-2391. [CrossRef] [PubMed]

214. Burnichon, N.; Vescovo, L.; Amar, L.; Libé, R.; de Reynies, A.; Venisse, A.; Jouanno, E.; Laurendeau, I.; Parfait, B.; Bertherat, J.; et al. Integrative genomic analysis reveals somatic mutations in pheochromocytoma and paraganglioma. Hum. Mol. Genet. 2011, 20, 3974-3985. [CrossRef] [PubMed]

215. Qin, N.; de Cubas, A.A.; Garcia-Martin, R.; Richter, S.; Peitzsch, M.; Menschikowski, M.; Lenders, J.W.; Timmers, H.J.; Mannelli, M.; Opocher, G.; et al. Opposing effects of HIF1a and HIF2a on chromaffin cell phenotypic features and tumor cell proliferation: Insights from MYC associated factor X. Int. J. Cancer 2014, 135, 2054-2064. [CrossRef] [PubMed]

216. Tian, H.; Hammer, R.E.; Matsumoto, A.M.; Russell, D.W.; McKnight, S.L. The hypoxia-responsive transcription factor EPAS1 is essential for catecholamine homeostasis and protection against heart failure during embryonic development. Genes Dev. 1998, 12, 3320-3324. [CrossRef] [PubMed]

217. Favier, J.; Kempf, H.; Corvol, P.; Casc, J.M. Cloning and expression pattern of EPAS1 in the chicken embryo. Colocalization with tyrosine hydroxylase. FEBS Lett. 1999, 462, 19-24. [CrossRef]

218. Nilsson, H.; Jögi, A.; Beckman, S.; Harris, A.L.; Poellinger, L.; Pahlman, S. HIF-2alpha expression in human fetal paraganglia and neuroblastoma: Relation to sympathetic differentiation, glucose deficiency, and hypoxia. Exp. Cell Res. 2005, 303, 447-456. [CrossRef]

219. Wang, H.; Cui, J.; Yang, C.; Rosenblum, R.S.; Zhang, Q.; Song, Q.; Pang, Y.; Fang, F.; Sun, M.; Dmitriev, P. A transgenic mouse model of Pacak-Zhuang syndrome with an EPAS1 gain of function mutation. Cancers 2019, 11, 667. [CrossRef] [PubMed]

220. Burnichon, N.; Cascon, A.; Schiavi, F.; Morales, N.P.; Comino-Mendez, I.; Abermil, N.; Inglada-Perez, L.; de Cubas, A.A.; Amar, L.; Barontini, M.; et al. MAX mutations cause hereditary and sporadic pheochromocytoma and paraganglioma. Clin. Cancer Res. 2012, 18, 2828-2837. [CrossRef] [PubMed]

221. Lloyd, R.V.; Osamura, R.Y.; Kloppel, G.; Rosai, J. WHO Classification of Tumours: Pathology and Genetics of Tumours of Endocrine Organs, 4th ed.; IARC: Lyon, France, 2017.

222. Tischler, A.S.; de Krijger, R.R. Pathology of pheochromocytoma and paraganglioma. Endocr. Relat. Cancer 2015, 22, 123-133. [CrossRef]

223. Thompson, L.D. Pheochromocytoma of the adrenal gland scaled score (PASS) to separate benign from malignant neoplasms: A clinicopathological and immunophenotypic study of 100 cases. Am. J. Surg. Pathol. 2002, 26, 551-566. [CrossRef]

224. Wu, D.; Tischler, A.S.; Lloyd, R.V.; DeLellis, R.A.; de Krijger, R.; van Nederveen, F.; Nosé, V. Obserer variation in the application of the pheochromocytoma of the adrenal gland scaled score. Am. J. Surg. Pathol. 2009, 33, 599-608. [CrossRef] [PubMed]

225. Kimura, N.; Takayanagi, R.; Takizawa, N.; Itagaki, E.; Katabami, T.; Kakoi, N.; Rakugi, H.; Ikeda, Y.; Tanabe, A.; Nigawara, T.; et al. Pathological grading for predicting metastasis in phaeochromocytoma and paraganglioma. Endocr. Relat. Cancer 2014, 21, 405-414. [CrossRef] [PubMed]

226. Szalat, A.; Fraenkel, M.; Doviner, V.; Salmon, A.; Gross, D.J. Malignant pheochromocytoma: Predictive factors of malignancy and clinical course in 16 patients at a single tertiary medical center. Endocrine 2010, 39, 160-166. [CrossRef] [PubMed]

227. Ayala-Ramirez, M.; Feng, L.; Johnson, M.M.; Ejaz, S.; Habra, M.A.; Rich, T.; Busaidy, N.; Cote, G.J.; Perrier, N.; Phan, A.; et al. Clinical risk factors for malignancy and overall survival in patients with pheochromocytomas and sympathetic paragangliomas: Primary tumor size and primary tumor location as prognostic indicators. J. Clin. Endocrinol. Metab. 2011, 96, 717-725. [CrossRef] [PubMed]

228. Goffredo, P.; Sosa, J.A.; Roman, S.A. Malignant pheochromocytoma and paraganglioma; a population level analysis of long-term survival over two decades. J. Surg. Oncol. 2013, 107, 659-664. [CrossRef] [PubMed]

229. Hamidi, O.; Young, W.F., Jr.; Iniguez-Ariza, N.M.; Kittah, N.E.; Gruber, L.; Bancos, C.; Tamhane, S.; Bancos, I. Malignant pheochromocytoma and paraganglioma: 272 patients over 55 years. J. Clin. Endocrinol. Metab. 2017, 102, 3296-3305. [CrossRef] [PubMed] 
230. Hescot, S.; Curras-Freixes, M.; Deutschbein, T.; van Berkel, A.; Vezzosi, D.; Amar, L.; de la Fouchardiere, C.; Valdes, N.; Riccardi, F.; Do Cao, C.; et al. Prognosis of malignant pheochromocytoma and paraganglioma (MAPP Prono Study): A European Network for the Study of Adrenal Tumors Retrospective Study. J. Clin. Endocrinol. Metab. 2019, 104, 2367-2374. [CrossRef]

231. Amar, L.; Bertherat, J.; Baudin, E.; Ajzenberg, C.; Bressac-de Paillerets, B.; Chabre, O.; Chamontin, B.; Delemer, B.; Giraud, S.; Murat, A. Genetic testing in pheochromocytoma or functional paraganglioma. J. Clin. Oncol. 2005, 23, 8812-8818. [CrossRef]

232. Amar, L.; Baudin, E.; Burnichon, N.; Peyrard, S.; Silvera, S.; Bertherat, J.; Bertagna, X.; Schlumberger, M.; Jeunemaitre, X.; Gimenez-Roqueplo, A.P.; et al. Succinate dehydrogenase B gene mutations predict survival in patients with malignant pheochromocytomas or paragangliomas. J. Clin. Endocrinol. Metab. 2007, 92, 3822-3828. [CrossRef]

233. Burnichon, N.; Rohmer, V.; Amar, L.; Herman, P.; Leboulleux, S.; Darrouzet, V.; Niccoli, P.; Gaillard, D.; Chabrier, G.; Chabolle, F.; et al. The succinate dehydrogenase genetic testing in a large prospective series of patients with paragangliomas. J. Clin. Endocrinol. Metab. 2009, 94, 2817-2827. [CrossRef]

234. Castro-Vega, L.J.; Buffet, A.; De Cubas, A.A.; Cascon, A.; Menara, M.; Khalifa, E.; Amar, L.; Azriel, S.; Bourdeau, I.; Chabre, O.; et al. Germline mutations in FH confer predisposition to malignant pheochromocytomas and paragangliomas. Hum. Mol. Genet. 2014, 23, 2440-2446. [CrossRef] [PubMed]

235. Buffet, A.; Morin, A.; Castro-Vega, L.J.; Habarou, F.; Lussey-Lepoutre, C.; Letouzé, E.; Lefebvre, H.; Guilhem, I.; Haissaguerre, M.; Raingeard, I.; et al. Germline mutations in the mitochrondrial 2-oxoglutarate/malate carrier SLC25A11 gene confer a predisposition to metastatic paragangliomas. Cancer Res. 2018, 78, 1914-1922. [CrossRef] [PubMed]

236. Bausch, B.; Schiavi, F.; Ni, Y.; Welander, J.; Patocs, A.; Ngeow, J.; Wellner, U.; Malinoc, A.; Taschin, E.; Barbon, G.; et al. Clinical characterization of the pheochromocytoma and paraganglioma susceptibility genes SDHA, TMEM127, MAX, and SDHAF2 for gene-informed prevention. JAMA Oncol. 2017, 3, 1204-1212. [CrossRef] [PubMed]

237. Eisenhofer, G.; Lenders, J.W.; Siegert, G.; Bornstein, S.R.; Friberg, P.; Milosevic, D.; Mannelli, M.; Linehan, W.M.; Adams, K.; Timmers, H.J.; et al. Plasma methoxytyramine; a novel biomarker of metastatic pheochromocytoma and paraganglioma in relation to established risk factors of tumor size, location and SDHB mutation status. Eur. J. Cancer 2012, 48, 1739-1749. [CrossRef] [PubMed]

238. Peitzsch, M.; Prejbisz, A.; Kroi $\beta$, M.; Beuschlein, F.; Arlt, W.; Januszewicz, A.; Siegert, G.; Eisenhofer, G. Analysis of plasma 3-methoxytyramine, normetanephrine and metanephrine by ultraperformance liquid chromatography tandem mass spectrometry: Utility for diagnosis of dopamineproducing metastatic phaeochromocytoma. Ann. Clin. Biochem. 2013, 50, 147-155. [CrossRef]

239. Van der Harst, E.; de Herder, W.W.; de Krijger, R.R.; Bruining, H.A.; Bonjer, H.J.; Lamberts, S.W.; van den Meiracker, A.H.; Stijnen, T.H.; Boomsma, F. The value of plasma markers for the clinical behaviour of phaeochromocytomas. Eur. J. Endocrinol. 2002, 147, 85-94. [CrossRef] [PubMed]

240. Sue, M.; Martucci, V.; Frey, F.; Lenders, J.M.; Timmers, H.J.; Peczkowska, M.; Prejbisz, A.; Swantje, B.; Bornstein, S.R.; Arlt, W.; et al. Lack of utility of SDHB mutation testing in adrenergic metastatic phaeochromocytoma. Eur. J. Endocrinol. 2015, 172, 89-95. [CrossRef]

241. Selak, M.A.; Armour, S.M.; MacKenzie, E.D.; Boulahbel, H.; Watson, D.G.; Mansfield, K.D.; Pan, Y.; Simon, M.C.; Thompson, C.B.; Gottlieb, E. Succinate links TCA cycle dysfunction to oncogenesis by inhibiting HIF-alpha prolyl hydroxylase. Cancer Cell 2005, 7, 77-85. [CrossRef]

242. Xiao, M.; Yang, H.; Xu, W.; Ma, S.; Lin, H.; Zhu, H.; Liu, L.; Liu, Y.; Yang, C.; Xu, Y.; et al. Inhibition of alpha-KG-dependent histone and DNA demethylases by fumarate and succinate that are accumulated in mutations of FH and SDH tumor suppressors. Genes Dev. 2012, 26, 1326-1338. [CrossRef]

243. Richter, S.; Peitzsch, M.; Rapizzi, E.; Lenders, J.W.; Qin, N.; de Cubas, A.A.; Schiavi, F.; Rao, J.U.; Beuschlein, F.; Quinkler, M.; et al. Krebs cycle metabolite profiling for identification and stratification of pheochromocytoma/paragangliomas due to succinate dehydrogenase deficiency. J. Clin. Endocrinol. Metab. 2014, 99, 3903-3911. [CrossRef]

244. Ploumakis, A.; Coleman, M.L. OH, the places you'll go! Hydroxylation, gene expression and cancer. Mol. Cell 2015, 58, 729-741. [CrossRef] [PubMed] 
245. Barollo, S.; Bertazza, L.; Watutantrige-Fernando, S.; Censi, S.; Cavedon, E.; Galuppini, F.; Pennelli, G.; Fassina, A.; Citton, M.; Rubin, B.; et al. Overexpression of L-type amino acid transporter 1 (LAT1) and 2 (LAT2): Novel markers of neuroendocrine tumors. PLoS ONE 2016, 11, e0156044. [CrossRef] [PubMed]

246. Yanagida, O.; Kanai, Y.; Chairoungdua, A.; Kim, D.K.; Segawa, H.; Nii, T.; Cha, S.H.; Matsuo, H.; Fukushima, J.; Fukasawa, Y.; et al. Human L-type amino acid transporter 1 (LAT1): Characterization of function and expression in tumour cell lines. Biochem. Biophys. Acta 2001, 1, 291-302. [CrossRef]

247. Zhao, Y.; Wang, L.; Pan, J. The role of L-type amino acid transporter 1 in human tumours. Intractable Rare Dis. Res. 2015, 4, 165-169. [CrossRef] [PubMed]

248. Kongpracha, P.; Nagamori, S.; Wiriyasermkul, P.; Tanaka, Y.; Kaneda, K.; Okuda, S.; Ohgaki, R.; Kanai, Y. Structure-activity relationship of novel series of inhibitors for cancer type transporter L-type amino acid transporter 1 (LAT1). J. Pharmacol. Sci. 2017, 133, 96-102. [CrossRef] [PubMed]

249. Lamberti, G.; Brighi, N.; Maggio, I.; Manuzzi, L.; Peterle, C.; Ambrosini, V.; Ricci, C.; Casadei, R.; Campana, D. The role of the mTOR in neuroendocrine tumors: Future cornerstone of a winning strategy? Int. J. Mol. Sci. 2018, 19, 747. [CrossRef]

250. Willenberg, H.S.; Schott, M.; Saeger, W.; Tries, A.; Scherbaum, W.A.; Bornstein, S.R. Expression of connexins in chromaffin cells of normal human adrenals and in benign and malignant pheochromocytomas. Ann. N. Y. Acad. Sci. 2006, 1073, 578-583. [CrossRef] [PubMed]

(C) 2019 by the authors. Licensee MDPI, Basel, Switzerland. This article is an open access article distributed under the terms and conditions of the Creative Commons Attribution (CC BY) license (http://creativecommons.org/licenses/by/4.0/). 